3 jiv SANDIA REPORT SAND81-0708 • Unlimited Release • UC-25

Printed January 1982

24601715

\title{
The Effect of Glass-Ceramic- Processing Cycle on the Metallurgical Properties of Candidate Alloys for Actuator Housings
}

\author{
Lawrence J. Weirick
}

Prepared by

Sandia National Laboratories

Albuquerque, New Mexico $\mathbf{8 7 1 8 5}$ and Livermore, California 94550

for the United States Department of Energy

under Contract DE-AC04-76DP00789

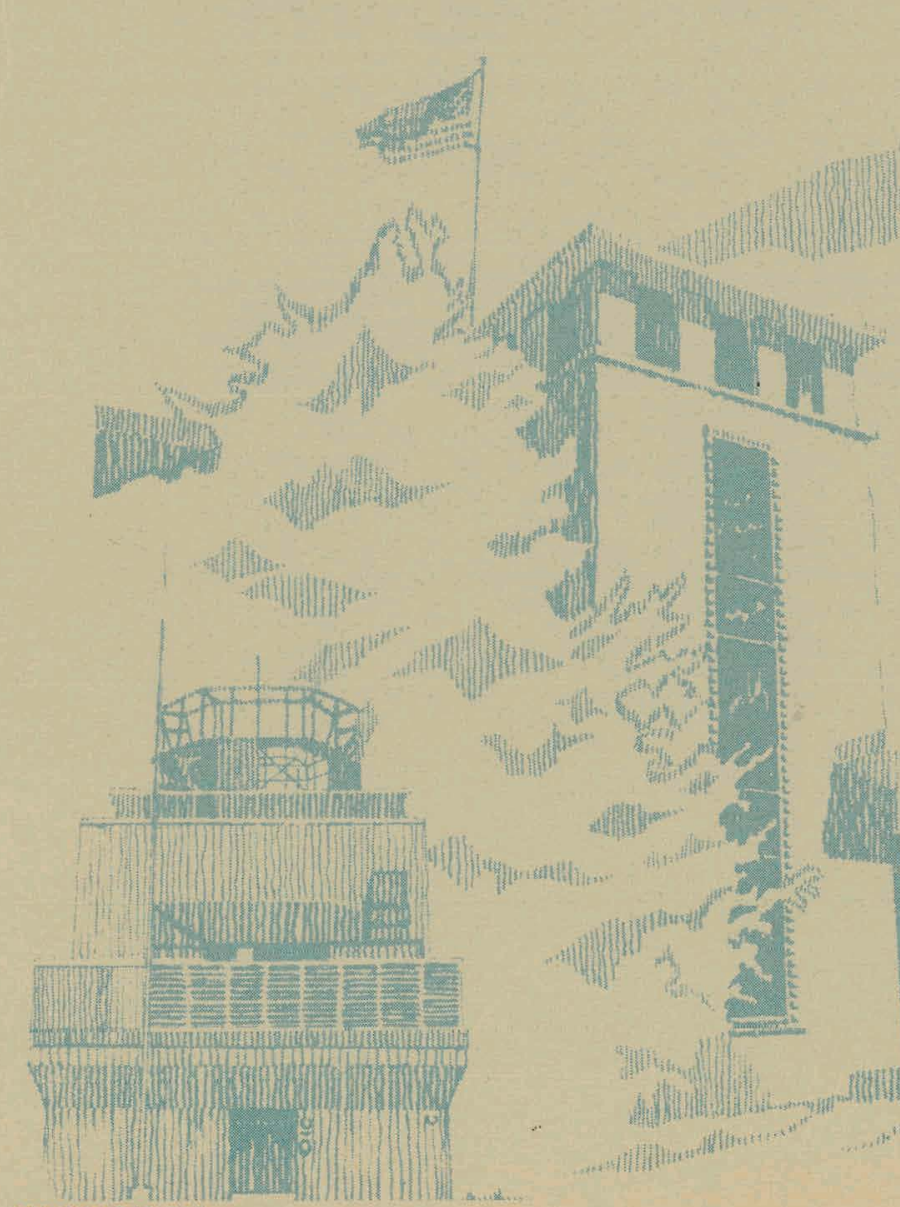




\section{DISCLAIMER}

This report was prepared as an account of work sponsored by an agency of the United States Government. Neither the United States Government nor any agency Thereof, nor any of their employees, makes any warranty, express or implied, or assumes any legal liability or responsibility for the accuracy, completeness, or usefulness of any information, apparatus, product, or process disclosed, or represents that its use would not infringe privately owned rights. Reference herein to any specific commercial product, process, or service by trade name, trademark, manufacturer, or otherwise does not necessarily constitute or imply its endorsement, recommendation, or favoring by the United States Government or any agency thereof. The views and opinions of authors expressed herein do not necessarily state or reflect those of the United States Government or any agency thereof. 


\section{DISCLAIMER}

Portions of this document may be illegible in electronic image products. Images are produced from the best available original document. 
Issued by Sandia National Laboratories, operated for the United States Department of Energy by Sandia Corporation.

NOTICE: This report was prepared as an account of work sponsored by an agency of the United States Government. Neither the United States Government nor any agency thereof, nor any of their employees, nor any of their contractors, subcontractors, or their employees, makes any warranty, express or implied, or assumes any legal liability or responsibility for the accuracy, completeness, or usefulness of any information, apparatus, product, or procompleteness, or usefulness of any information, apparatus, product, or process disclosed, or represents that its use would not infringe privately owned
rights. Reference herein to any specific commercial product, process, or rights. Reference herein to any specific commercial product, process, or
service by trade name, trademark, manufacturer, or otherwise, does not necessarily constitute or imply its endorsement, recommendation, or favoring by the United States Government, any agency thereof or any of their contractors or subcontractors. The views and opinions expressed herein do not necessarily state or reflect those of the United States Government, any agency thereof or any of their contractors or subcontractors.

Printed in the United States of Americe Available from

Avational Technical Information Service

U.S. Department of Commerce

5285 Port Royal Road

Springfield, VA 22161

NTIS price codes

Printed copy: $\$ 6.00$

Microfiche copy: A01 
THE EFFECT OF GLASS-CERAMIC-PROCESSING CYCLE ON THE METALLURGICAL PROPERTIES OF CANDIDATE ALLOYS FOR ACTUATOR HOUSINGS

\author{
L. J. Weirick
}

\title{
ABSTRACT
}

This report summarizes. the results from an investigation on the effect of a glass ceramic processing cycle on the metallurgical properties of metal candidates for actuator housings. The cycle consists of a $980^{\circ} \mathrm{C}$ sealing step, a $650^{\circ} \mathrm{C}$ crystallization step and a $475^{\circ} \mathrm{C}$ annealing step. These temperature excursions are within the same temperature regime as annealing and heat treating processes normaliy employed for metals. Therefore, the effect of the processing cycle on metallurgical properties of microstructure, strength, hardness and ductility were examined. It was

found that metal candidates which are single phase or solid solution alloys (such as 21-6-9, Hastelloy C-276 and Inconel 625) were not affected whereas multiphase or precipitation hardened alloys (such as Inconel 718 and Titanium $B-C$ ) were changed by the processing cycle for the glass ceramic.

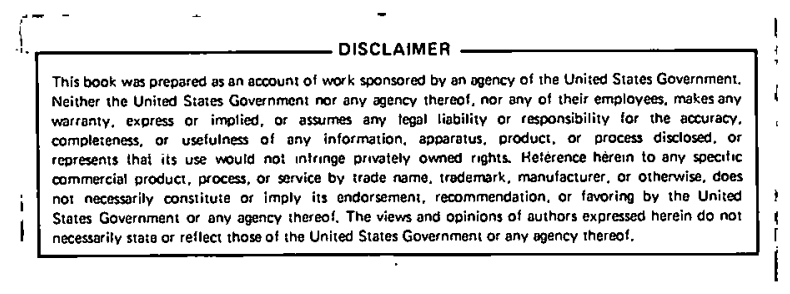




\section{Outline}

Page

Abstract

Introduction

5

Experimental Procedure. 8

Results and Discussion

$2: 1-6-9$

10

Hastelloy C-276

Inconel 625

Inconel 718

11

Titanium $B-C$ 15

Conclusions 16

Recommendations 17

References

Acknowledgments 


\section{INTRODUCTION}

An example of the design of a standard actuator is shown in Figure 1. It is comprised of an external metal housing, an insulator, electrical contact pins, a bridgewire and an integral charge holder which is filled with either a pyrotechnic or high explosive mixture. Traditionally, glass has been used as the insulating material between pins and between pins and metal housing. The use of glass necessitated the use of metals for pins and housings which could be reliably sealed to glass. This materials fabrication requirement reduced the number of possible metallic candidates to a few. Because actuators also must exhibit some structural strength in order to produce an energy pulse or shock wave, the metal housing needed to possess adequate strength for a given design. Iron alloys thus became traditional in actuators with glass insulators. Two of the most commonly used iron alloys for actuator housings are 304 and 21-6-9 stainless steels. The pin material is usually Niron 52 (Fe-52Ni).

When the need for actuators which produced a higher impulse by a higher pressure transient arose, the glass insulating material was replaced by a ceramic. Currently, the most common ceramic employed in these actuators is alumina. It is fabricated into shapes for insulator designis by pressing and sintering techniques. These ceramic insulators then have their surfaces metallized and are brazed to the metal pins and housings. Because the matching of thermal expansion coefficients between metal and ceramic is important in this fabrication technique, Kovar pins are required in 
these actuator designs.

Today, technology calls for an even higher pressure pulse and corrosion resistant pins. This necessitates the change of the insulating material, the metallic housing and the pins. Glass ceramics are being developed to satisfy the insulating material requirements for both strength and sealing ability. Metal alloys that have not traditionally been used for the housing and one that has been used recently, as a standard (21-6-9), have been selected as candidates for a current application and a program has begun to qualify them. The requirements on these alloys include moderate to high strength, low thermal expansion coefficient, good fracture toughness, good weldability, easy machineability and good corrosion resistance. The five alloys that are being considered as candidates for the metal housing or pins for glass ceramic actuators are 21-6-9 stainless steel, Hastelloy C-276, Inconel 625 and Inconel 718, which are nickel-base alloys, and Titanium $B-C$. The composition of these five alloys are given in Table I. Properties which are important for selection as a housing candidate are given in Table II. The primary property the metal candidate must have in order to be carried as a candidate is corrosion resistance, particularly to environments which contain chloride. The cost of the housing is affected significantly by ease of machinability. The cost differential can be as much as an order of magnitude (i.e., from $\$ 10$ to $\$ 100$ per housing). For most glass ceramic compositions, thermal expansion compatibility with metal housings is best when the metals have low coefficients of expansion. 
The properties for each candidate. suggest's the following: 21-6-9 is the least acceptable of the five candidates and since it is the metal which is presently used, replacement is desirable. Hastelloy C-276 is available, has excellent corrosion resistance, a low thermal expansion coefficient and moderate strength.' However, its poor machinability results in expensive hardware items. Inconel 625 has the best combination of properties if a glass ceramic composition can be found to match its moderate thermal expansion coefficient and the design of the actuator doès not demand very high strength." Inconel 625 does have good strength.

The last two alloy candidates need special consideration when the strength requirements for the housing are very high. Inconel 718 has a good combination of all properties. The challenge in using this alloy is to find a glass ceramic composition which will have a rather high, matching thermal expansion cóefficient. Titanium $B-C$ has all the right physical and chemical properties for a metal candidate. It has not been used previously"in a" hardware item which requires sealing to an insulator.

The present study addresses one aspect of this selection process; namely, the effect of the glass ceramic processing cycle on the microstructure and mechanical properties of the mating metal housing. Other studies are in progress concerning other selection criteria such as weldability, machinability, pyrotechnic compatibility and glass ceramic sealing ease. 
EXPERIMENTAL PROCEDURE

Tensile specimens were made from rods of each of the five candidate alloys. These specimens were subjected to specific heat treatments within the glasss ceramic processing cycle and then mechanically tested. The glass ceramic processing cycle is shown in Figure 2. The primary steps were first the glass sealing step which was done at $980^{\circ} \mathrm{C}$ for approximately 10 minutes, and second, the ceramic recrystalization and growth steps which were done at $650^{\circ} \mathrm{C}$ and $475^{\circ} \mathrm{C}$ for 1 hour each, respectively, Heat treatment conditions for many metal alloy systems are similar to these temperatures and times. More explicitly, the glass sealing step at $980^{\circ} \mathrm{C}$ for approximately 10.minutes correlates with annealing heat treatments of many metal alloys. The çrystallization and annealing steps for the sealing process correlate in temperature with aging heat treatments for many metal alloys. Finally, the effect of these heat treatments on the mechanical properties of the candidate alloys is the information desired from this study.

One procedure was used for those alloys which are single phase or solid solution alloys, that is., for 21-6-9, Hastelloy C-276 and Inconel 625, Three metallurgical conditions were examined. First, the material was tested in the condition received from the supplier. Second, the specimens were subjected to the glass sealing treatment, i.e., annealed. Third, the specimens were run through the entire glass ceraming process, $i . e .$, annealed and aged.

A second procedure was used for those alloys which are duplex or multiphase alloys, that is, for Inconel 718 and Titanium $\beta-C$. 
Five metallurgical conditions were examined. First, the material, ' was tested in the fully heat-treated or hardened condition. Second, the specimens were fully-hardened and then subjected to the glass sealing treatment, i.e., annealed. Third, the specimens were fully hardened and then run through the entire glass ceraming process, i.e., annealed and aged. Fourth, the material was fully hardened, then run through the entire glass ceraming process and finally, again fully hardened. Fifth, the specimens were subjected to the glass ceraming process and then fully hardened.

The tensile specimens were pulled on an Instron machine at a strain rate of $0.005 \mathrm{sec}$, i.e., a usual strain rate. A clipon extensometer was used to obtain the complete record of load versus elongation for each specimen. The yield strength, ulti- . mate tensile strength and elongation were then calculated. In addition, hardness measurements were made on selected specimens.

A piece of each broken tensile specimen was used for the metallographic determination of the microstructures corresponding to the heat treatments and mechanical properties. In addition, scanning electron microscopy of the titanium $\beta-C$ fracture surfaces was done. These results are discussed in the next section of this report.

The heat treat schedule used to fully harden Inconel 718 is as follows: ${ }^{1}$

1. Anneal at $1010^{\circ} \mathrm{C}\left(1850^{\circ} \mathrm{F}\right)$ for one hour.

2. Furnace cool to $720^{\circ} \mathrm{C}\left(1325^{\circ} \mathrm{F}\right)$

3. Age at $720^{\circ} \mathrm{C}\left(1325^{\circ} \mathrm{F}\right)$ for eight hours.

4. Furidace cool to $620^{\circ} \mathrm{C}$ (I $\left.150^{\circ} \mathrm{F}\right)$. 
5. Age at $620^{\circ} \mathrm{C}\left(1150^{\circ} \mathrm{F}\right)$ for eight hours.

6. Air cool.

The heat treat schedule used to fully harden titanium $\beta-C$ is as follows: Age at $550^{\circ} \mathrm{C}$ for eight hours.

\section{RESULTS AND DISCUSSION}

$\underline{21-6-9}$

The mechanical property data for the 21-6-9 stainless steel specimens are given in Table III. The material received from the supplier was in a cold-worked, partially recrystallized condition as shown in Figure 4a. Subjecting this material to the vacuum firing step caused a full recrystallization of the material and significant grain growth as shown in Figure $4 \mathrm{~b}$. This process reduced the strength but increased the ductility and resulted in baseline properties for 21-6-9. The additional processing steps simulating crystallization of the glass ceramic caused some secondary recrystallization in the metal microstructure as shown in Figure 4c. This step increased the strength and decreased the ductility approximately 10\%, respectively. It can also be seen in the microstructures of Figures $4 \mathrm{~b}$ and $4 \mathrm{c}$ that a precipitate has formed along the grain boundaries. This precipitate $\left(\mathrm{Cr}_{23} \mathrm{C}_{6}\right)$ is identified with a phenomena in austenitic stainless steels called "sensitization." When this precipilation becomes pronuuncud, Lhe material is susceptible to SCC or embrittlement by the environment. Hastelloy $\mathrm{C}-276$

The mechanical property data for the Hastelloy C-276 specimens are given in Table III. The material received from the supplier was in an annealed condition as shown in Figure 5a. Vacuum 
firing produced some recrystallization of the microstructure as shown in Figure $5 \mathrm{~b}$ which was accompanied by a small reduction in strength and increase in ductility. The final aging step did not produce any further change in either microstructure or mechanical properties, Figure 5c. Thus, the glass-ceramic processing cycle does not have a detrimental effect on the properties of Hastelloy C-276.

\section{Inconel 625}

Figures $6 \mathrm{a}, 6 \mathrm{~b}$ and $6 \mathrm{c}$ show the microstructures of the Inconel 625 specimens in the "received from supplier," vacuum fired and vacuum fired plus ceraming cycle, respectively. It can be seen that the microstructure was initially in the annealed condition and remained unchanged by additional heat treatments. Since the standard annealing temperature for Inconel 625 is between 930 to $1040^{\circ} \mathrm{C}$ $\left(1700\right.$ to $\left.1900^{\circ} \mathrm{F}\right), 2$ it was expected that any additional heat treatments within this temperature zone would have little, if any effect, on the material. The mechanical properties for the Inconel 625 specimens are given in Table III. The values obtained for the specimen "received from supplier" agreed well with those reported by the manufacturer ${ }^{2}$ for material annealed at $1010^{\circ} \mathrm{C}\left(1850^{\circ} \mathrm{F}\right)$ that is, Y.S. $=78.6 \mathrm{ksi}$, T.S. $=142.5 \mathrm{ksi}$ and $\mathrm{E} .=46 \%$ Further annealing at $1000^{\circ} \mathrm{C}$ had no effect as shown by the unchanged mechanical properties of the other two specimens. The qlass-ceramic processing cycle has no apparent effect on the properties of Inconel 625. Inconel 718

Inconel 718 is an age-hardenable, fcc, Ni-based material. Strength is largely dependent on the precipitation of a gamma prime phase following heat treatment. ${ }^{1}$ There was concern that 
the glass-ceramic processing cycle would alter the strength of the material by interference with the precipitation reaction. The material was therefore heat treated to the fully hardened condition as the starting point, This microstructure is shown in Figure 7a and the corresponding mechanical properties are given in Table IV. The fully hardened strength of Inconel 718 was very high, the ultimate tensile strength near $1400 \mathrm{MPa}(200 \mathrm{ksi})$. Subjecting this material to the vacuum firing process caused the gamma prime precipitate to solutionize into the gamma parent phase. ${ }^{3}$ The resulting microstructure for this annealed material is shown in Figure $7 b$. The obvious observation is that the microstructure for this annealed condition looks identical to that of the fully hardened material, i.e., at $250 \mathrm{x}$. The explanation is that the gamma prime phase is an extremely fine phase visible only by high magnification, high resolution transmission electron microscopy techniques. ${ }^{3}$ The evidence that the gamma prime phase had dissolved into the parent phase is given by the mechanica $\perp$ property data in 'lable IV. The strenylli of Llee annealed material was considerably less and the ductility was significantly higher than the values for the fully hardened material. These values for vacuum fired material agreed well with those given by Huntington Alloys ${ }^{1}$ for hot rolled $955^{\circ} \mathrm{C}\left(1750^{\circ} \mathrm{F}\right)$ annealed bar. Subjecting the annealed material to the crystallization process produced some aging (gamma prime precipitation) of the material as evidenced by the increased strength and reduced ductility values given in Table IV for this material condition. Again, the optical microscope did not reveal the process of aging, Figure 7c, that is, the precipitation of gamma prime phase. 
The purpose of the fourth and fifth material treatments for Inconel 718 was twofold. First, the question of whether the material can be brought back to a fully hardened condition by an additional heat treating step after ceraming was investigated. Second, the question of whether the starting condition (fully hardened versus annealed) affected the final mechanical properties after the intermediary steps, was examined. Table IV lists the mechanical properties obtained from specimens treated to these respective conditions. The strengths measured for both specimens were very high, experimentally comparable to those obtained for the specimen which had been only fully hardened. Analogously, the ductilities were comparable for all of the fully hardened specimens. Thus, Inconel 718 can be fully hardened after glass-ceramic processing and starting condition has no appreciable effect. The microstructures of these two specimens are shown in Figures $7 d$ and $7 e$, respectively. They look identical to the previous three, i.e., Figures 7a-7c. Again, the gamma prime precipitates were not visible at this magnification. In summary, with respect to microstructure, the mechanical property condition of Inconel 718 cannot be determined from a $250 x$ micrograph (or indeed with optical metallography in general).

The hardness of Inconel 718 as a function of material condition was measured with a diamond pyramid hardness tester. The hardness versus the yield strength and ultimate tensile strength are plotted in Figures 8 and 9, respectively. These plots show that there was a trend of increasing hardness with increasing strength. However, in various conditions of full hardness, the 
The heat treatment which normally fully hardens $\beta-C$ titanium (i.e., $500^{\circ} \mathrm{C}$ for 8 hours) was applied to the last two specimens at the end of their processing. The mechanical property data in Table IV shows that the specimens did not attain full strength, although some increase did occur. The microstructures for these specimens are shown in Figures $10 \mathrm{c}$ and $10 \mathrm{~d}$, respectively. The increase in strength was due to the formation of the alpha phase within the grains as a coarse precipitate. The large loss in ductility was most likely a result of the alpha precipitates along the grain boundaries not being able to maintain the load generated by the stronger grains. 5

In an attempt to better understand this embrittlement of $\beta-C$ titanium, scanning electron microscope (SEM) fractographs of the fracture surfaces were taken. These are shown, in sequence of material condition, by Figures lla through lle. Figure lla, the fully hardened material, showed the least amount of grain boundary fracture or faceting of the fracture set. The fracture was predominantly transgranular with evidence of fine, dimple-ductile rupture, Figure 12a. This result correlated well with the observed microstructure, Figure 10a, in that the predominant phase morphology was within the grains rather than at the grain boundaries. The microstructure of the annealed specimen, Figure 10b, shows very little inner grain morphology but significant decoration of alpha at the grain boundaries. The fracture morphology reflected this condition in that the fracture was predominantly intergranular but some transgranular fracture was evident, Figure 1lb. In addition, the grain facets show a significant amount of fine, dimple-ductile rupture, 
hardness was not a unique function of the strength. A measure of hardness can then only be used as an approximation. of the material condition, i.e., annealed, aged, hardened.

Titanium $B-C$

Titanium $B-C$ is an alloy of titanium which has sufficient alloy additions to stabilize the beta phase upon rapid cooling from the solutionizing temperature, above $885^{\circ} \mathrm{C}$. Subsequent aging of the alloy can produce a significant hardening by precipitation of alpha (the titanium rich phase) within the prior beta grains. 4 Being a metastable beta alloy, it does not undergo a phase change at $885^{\circ} \mathrm{C}$ while cooling from processing temperatures near $1000^{\circ} \mathrm{C}$, as the nonbeta alloys do, and thus a bond to a glass-ceramic should remain intact. Again the concern was the effect of a ceraming step on the final mechanical properties.

The mechanical properties received from the specimens placed in the five conditions are summarized in Table IV. The specimen in the fully hardened condition had very high yield strength and tensile strength with good ductility. The microstructure of the fully hardened specimen is shown in Figure 10a.. The prior beta grain boundaries were delineated by a denuded zone. Within the grains was a fine precipitate of alpha. Vacuum firing this material produced an annealed condition which softers the llaterial, iable IV, and gave the mirnstructure. shown in Figure 10b. This microstructure consisted primarily of beta with some silicide precipitates within the grains and alpha along the grain boundaries. 4 . Adding the ceraming step increased the precipitation of alpha on the grain boundaries which did not affect the strength of the alloy but did reduce the ductility value. This microstructure is shown in Figure 10c. 
Figure 12b. The good ductility of this material was due to this occurrence. Aging of the annealed matẹial during the ceraming process caused an increased decoration of the grain boundaries with alpha, Figure 10c, This event was reflected in the fracture morphology of this specimen, Figure 1lc, where the fracture was almost all intergranular. In addition, there was only a small amount of simple-ductile rupture on the grain facets, Figure $12 \mathrm{c}$.

The fractographs for the specimens which were given the $550^{\circ} \mathrm{C}$ 8 hour age after glass-ceramic processing are shown in Figures lld and lle. In both cases the fracture was almost exclusively intergranular. This occurrence was expected because of the heavy decoration of the grain boundaries with the alpha phase, as shown in the microstructures by Figures lod and 10e. Also, the low ductilities measured correlated with the small amount of dimple-ductile rupture observed on a few façets of grains of these specimens, Figures $12 \mathrm{~d}$ and 12e. Most of the grain facets exhibited sharp cleavage which reflected the brittleness of the alpha material.

In conclusion, the glass-ceramic processing procedure used in this set of tests cannot be applied to the titanium B-C alloy. Another set of parameters must be found which avoids the nucleation of the alpha phase at a temperature near $650^{\circ} \mathrm{C}$. Thus, moving the ceraming process temperature up or dowin from $650^{\circ} \mathrm{C}$ by perhaps $100^{\circ} \mathrm{C}$ will avoid the alpha phase nucleation and the material will not embrittle.

CONCLUSIONS

The single-phase or solid-solution alloys of 21-6-9 stainless steel, Hastelloy $\mathrm{C}-276$ and Inconel 625 were not affected by the 
glass-ceramic processing cycle to any significantly detrimental degree. The only change was a sensitization of the 21-6-9. Increased heat treat time in the nucleating-ceraming temperature zone could be detrimental to this alloy. Hastelloy C-276 and Inconel 625 were found to be totally compatible with the glassceramic processing cycle.

The multiphase or precipitation hardened alloys of Inconel 718 and titanium $\beta-C$ were affected by the glass-ceramic processing cycle. The Inconel 718 was softened by the vacuum firing step due to the redissolution of the gamma prime phase but recovered some strength during the nucleating-ceraming steps. Full recovery of properties was accomplished by following the ceraming step with the recognized heat treatment for fully hardening the material. Inconel 718 was found to be an acceptable metal candidate for actuator housings. Titanium $B-C$ was also softened by the vacuum firing step due to the redissolution of the alpha phase. It did not recover any strength during subsequent aging but lost ductility due to increased precipitation of alpha phase upon the grain boundaries. Adding a heat treatment in an attempt to fully harden the material produced some strengthening but the material became embrittled. Titanium $B-C$ in this condition is not an acceptable candidate for actuator housings.

RECOMMENDATIONS

21-6-9 stainless steel is currently being used to produce housings for actuators in production. It is an acceptable material for many designs. Its application is limitcd primarily 
by strength requirements of advanced actuator designs.

Hastelloy C-276 has only slightly increased strength over 21-6-9 and is not easily machined. It is not presently used nor is it recommended as a housing material for actuators. However, since it does have a low thermal expansion coefficient and is unaffected by glass-ceramic processing, it should be an acceptable material for other, simple and non-loadbearing, parts of an actuator, such as a pin.

Inconel 625 is being used for housings of actuator designs which require moderately high burst strengths. It is proving to be a good material because of ease of sealing to a glass-ceramic, reasonable machinability, good strength and it is not affected by processing.

Inconel 718 has recently been accepted as a housing material for actuator designs which require high burst strengths. Although the mechanical properties of Inconel 718 are affected by processing, a final heat treatment restores the full strength. This strength combined with acceptable glass-ceramic sealing properties, good machinability and excellent corrosion resistance makes Inconel 718 an excellent material for actuator housings.

Titanium $\beta-C$ has not been accepted as a material for actuator housings. A different processing schedule must be developed to avoid the material embrittlement problem. Difficulty is also being encountered with the glass-ceramic sealing procedure. Thus, the potential of titanium $\beta-C$ as a housing material still remains, but significant development effort is required for success. 


\section{REFERENCES}

1. Inconel alloy 718, Huntington Alloys, Inc., Huntington, West Virginia, 25720 .

2. Inconel alloy 625, Huntington Alloys, Inc., Huntington, West Virginia, 25720 .

3. H. L. Eiselstein, "Metallurgy of a Columbium-Hardened NickelChromium-Iron Alloy," Advances in the Technology of Stainless Steels and Related Alloys, Special Technical Publication No. 369. American Society for Testing and Materials, 1965.

4. T. J. Headley and H. J. Rack, "Phase Transformations in Ti3Al-8V-6Cr-4 $\mathrm{Zr}-4 \mathrm{MO}$, " Metallurgical Transactions A Vol. 10A, July 1979 .

5. H. J. Rack, "Grain Boundary Embrittlement in a Beta Titanium Alloy," Metallurgical Transactions A, Vo1. 6A, April 1975.

\section{ACKNOWLEDGEMENTS} people:

The author wishes to acknowledge the support of the following

C. J. Greenholt, 5841, for procuring the specimens.

S. T. Reed, 1471, for heat treating the specimens.

R. E. Blose, 5835, for mechanically testing the specimens.

M. E. McAllaster, 5822, for the metallographic information.

M. M. Sturm, 5822, for the SEM fractographic results.

H. J. Rack, 5835, for guidance with titanium alloys. 


\section{Compositions of Candidate Alloys}

21-6-9 stainless steel $21 \mathrm{Cr}, 6 \mathrm{Ni}, 9 \mathrm{Mn}, 0.3 \mathrm{~N}, 0.04 \mathrm{C}$ balance $\mathrm{Fe}$

Hastelloy $\mathrm{C}-276$ 16Mo, $15 \mathrm{Cr}, 6 \mathrm{Fe}, 4 \mathrm{~W}, 2,5 \mathrm{Co}, 0.08 \mathrm{C}$ balance $\mathrm{Ni}$

Inconel 625

$21 \mathrm{Cr}, 9 \mathrm{MO}, 3.6 \mathrm{Cb}+\mathrm{Ta}, 2.5 \mathrm{Fe}, 0.2 \mathrm{Al}$, $0.05 \mathrm{C}$

balance $\mathrm{Ni}$

Inconel 718

$19 \mathrm{Cr}, 18 \mathrm{Fe}, 3 \mathrm{Mo}, 5.1 \mathrm{Cb}+\mathrm{Ta}$, $0.9 \mathrm{Ti}, 0.04 \mathrm{C}$

balance $\mathrm{Ni}$

Titanium $B-C$

$8 \mathrm{~V}, 6 \mathrm{Cr}, 4 \mathrm{Zr}, 4 \mathrm{Mo}, 3 \mathrm{Al}$

balance $\mathrm{Ti}$ 
TABLE II

Properties of Candidate Alloys

\begin{tabular}{|c|c|c|c|c|}
\hline Alloy & $\begin{array}{l}\text { Corrosion } \\
\text { Resistance } \\
\end{array}$ & Machinability & $\begin{array}{c}\text { Thermal } \\
\text { Expansion } \\
\text { Coefficient } \\
\end{array}$ & $\begin{array}{l}\text { Ultimate } \\
\text { Tensile } \\
\text { Strength }\end{array}$ \\
\hline & & & $\times 10^{-7} /{ }^{\circ} \mathrm{C}$ & \\
\hline $21-6-9$ & Good & Fair & 190 & 112 \\
\hline $\begin{array}{l}\text { Hastelloy } \\
\qquad-276\end{array}$ & Excellent & Poor & 113 & 120 \\
\hline Inconel 625 & Excellent & Good & 144 & 150 \\
\hline Inconel 718 & Excellent & Good & 160 & 200 \\
\hline Titanium $\beta-C$ & Excellent & Fair & 106 & 210 \\
\hline
\end{tabular}


TABLE III

Mechanical Properties of Single Phase Alloys

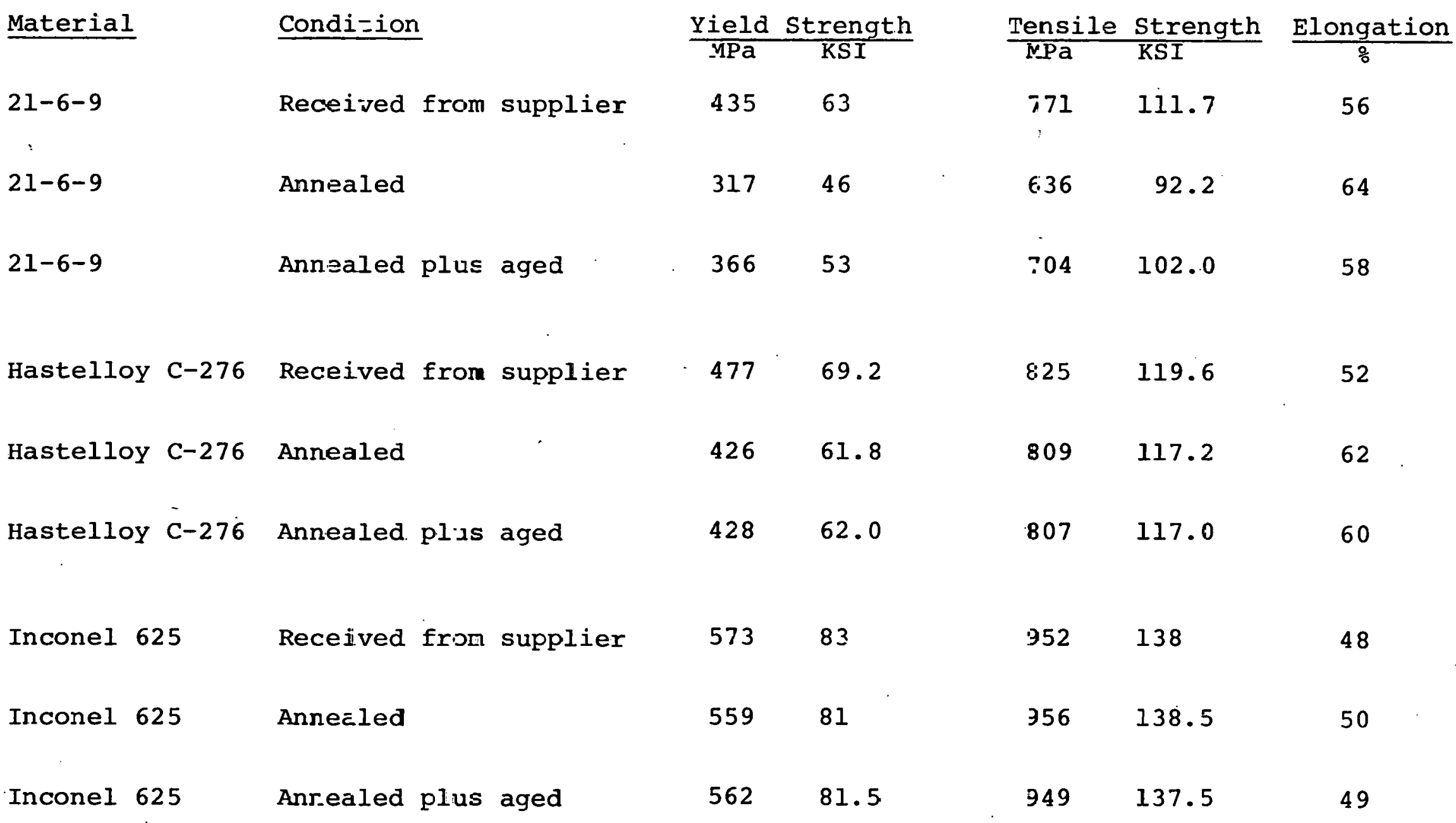


TABLE IV

Mecharical Properties of Multi-Phase Alloys

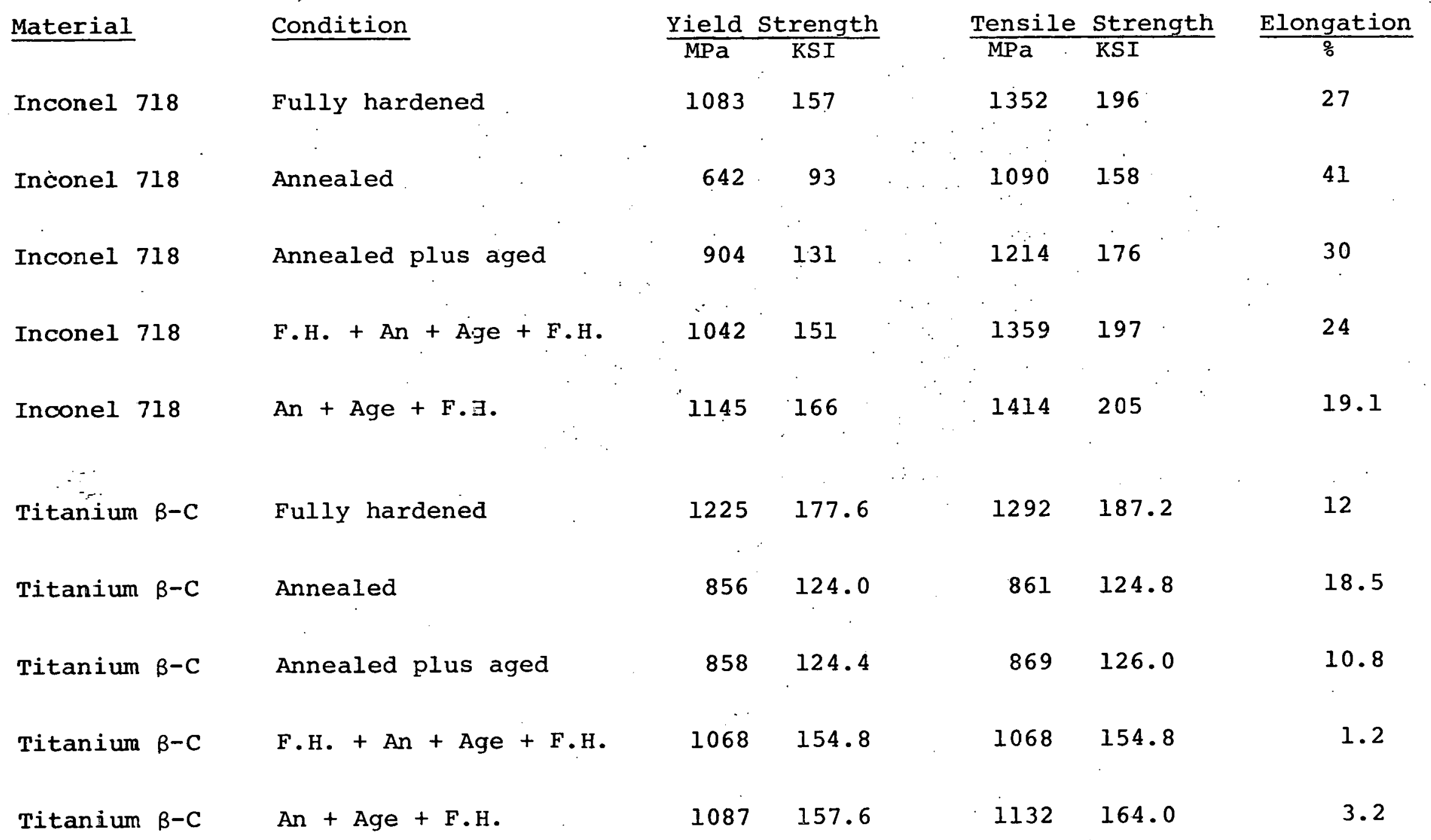




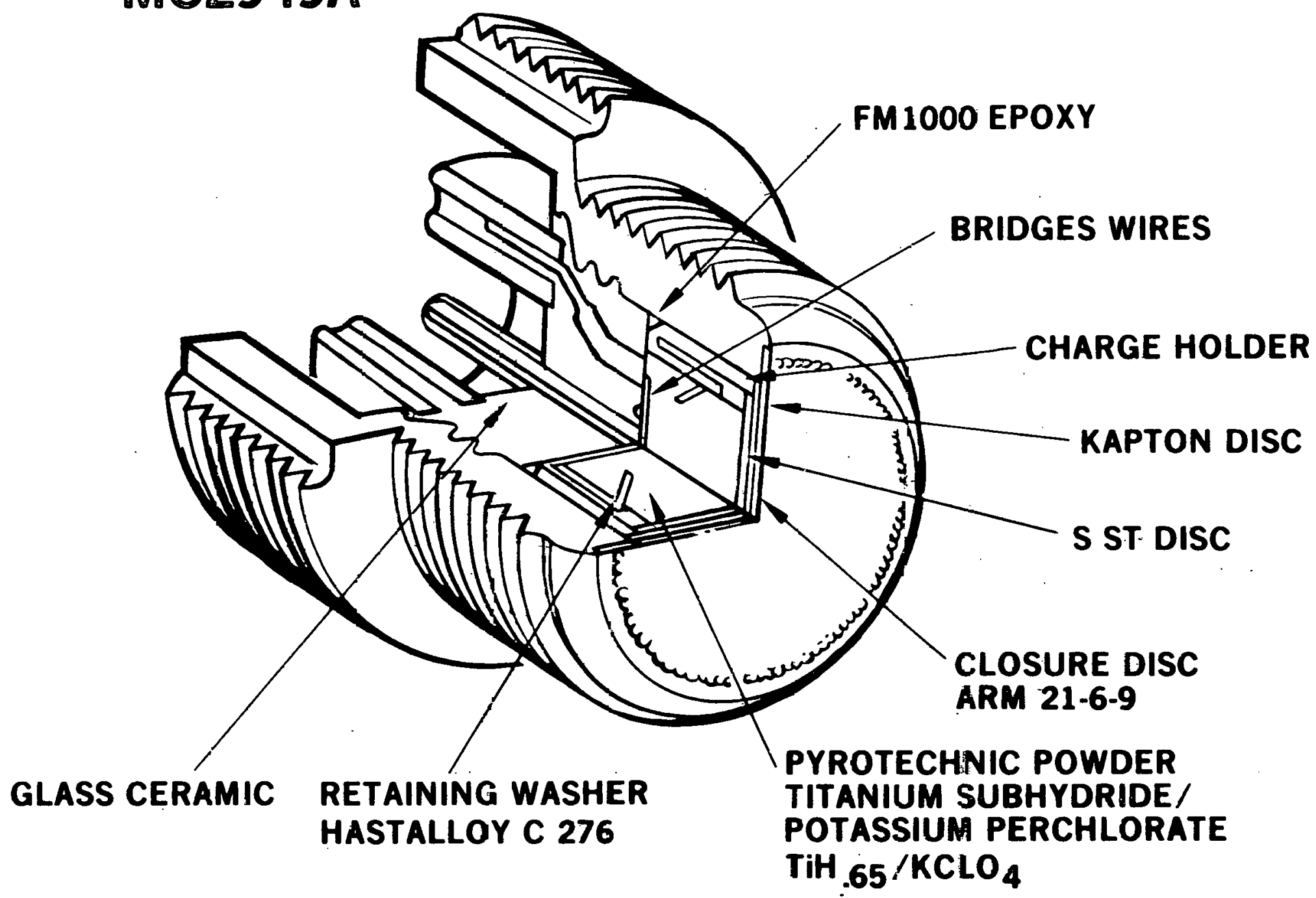

Figure 1. Cutaway View of MC 2949 A Istuator 


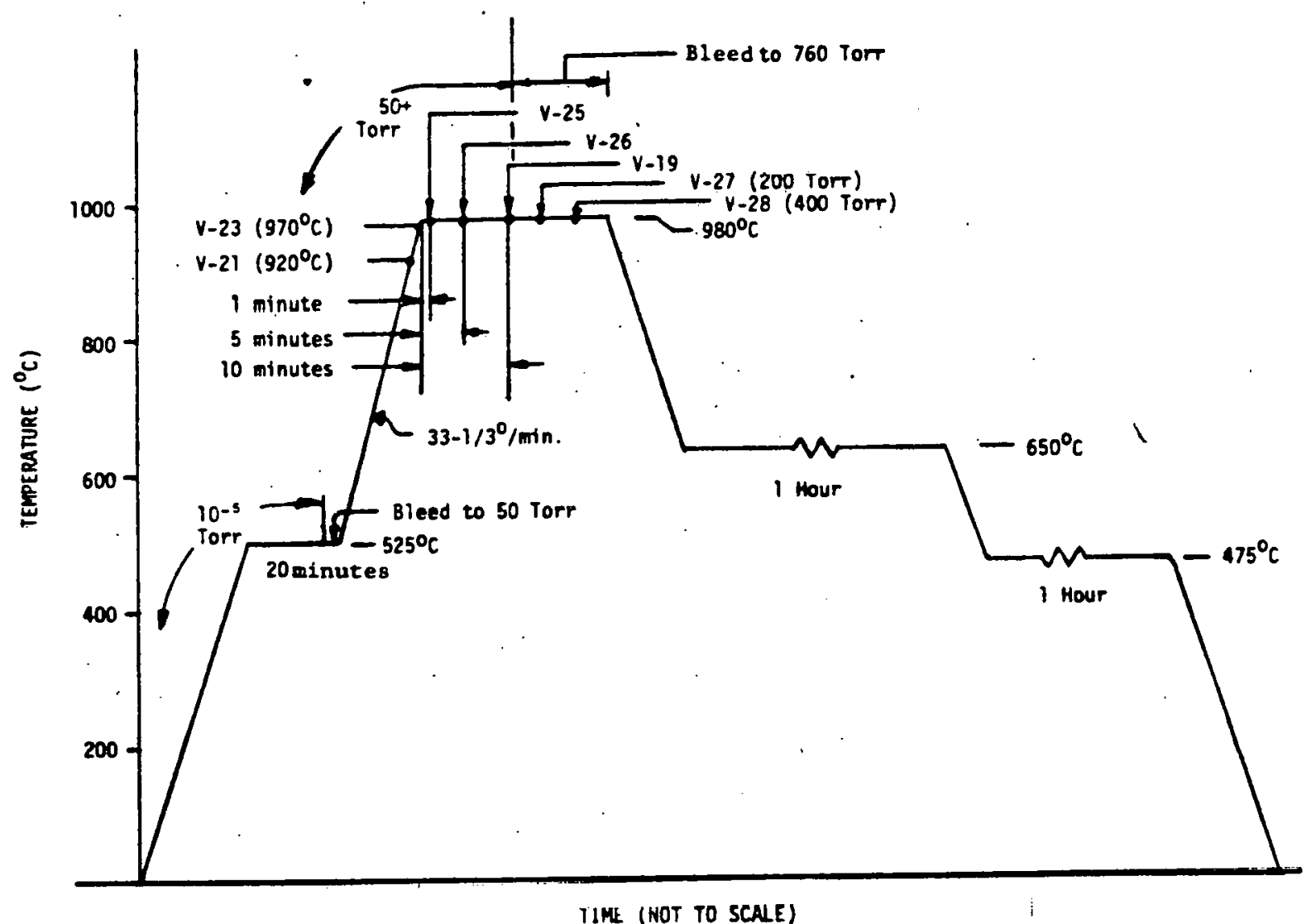

Figure 2. Time-Temperature Sealing Cycle 
N

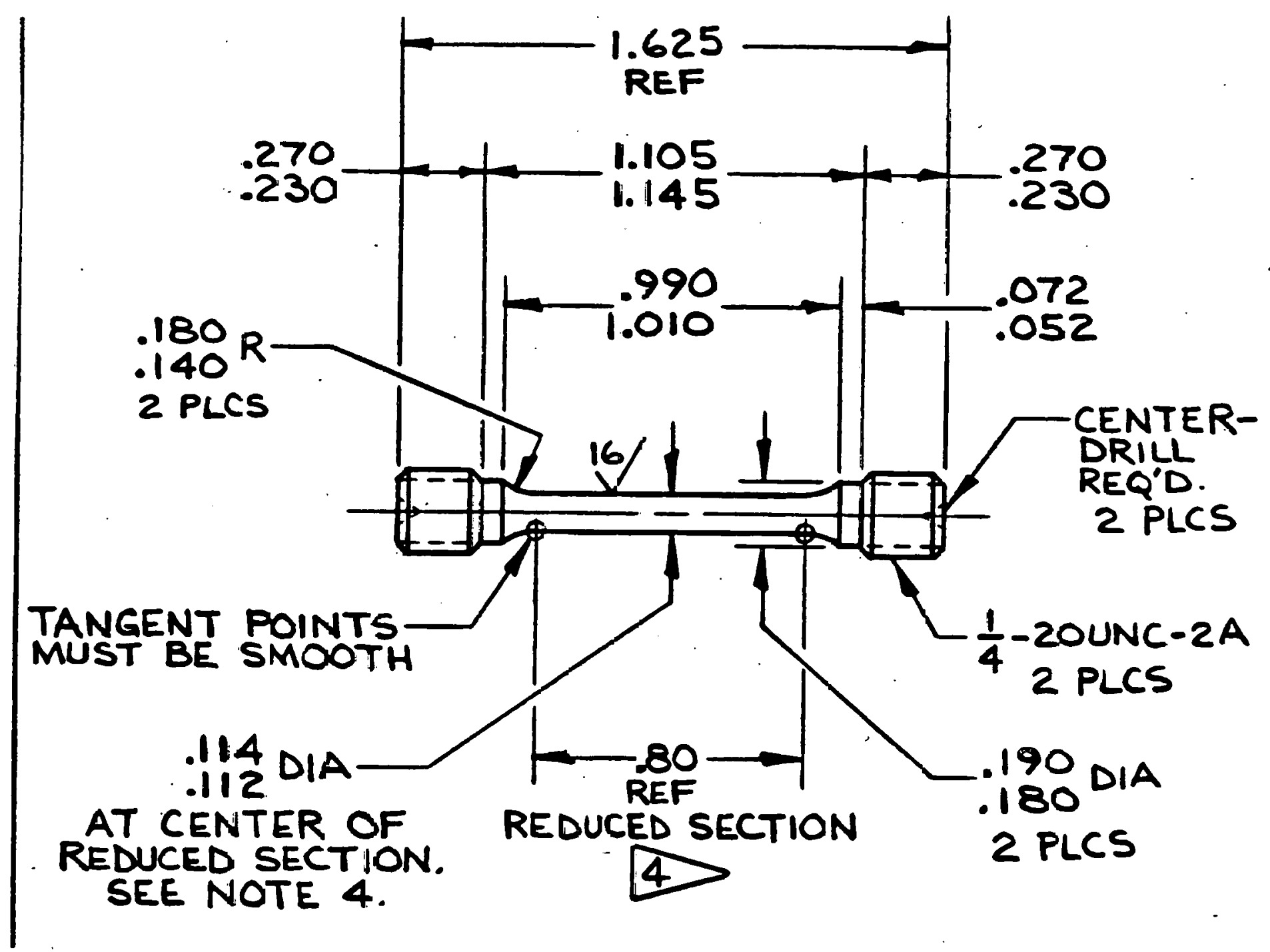

Figure 3. Drawing of Tensile Specimen. 


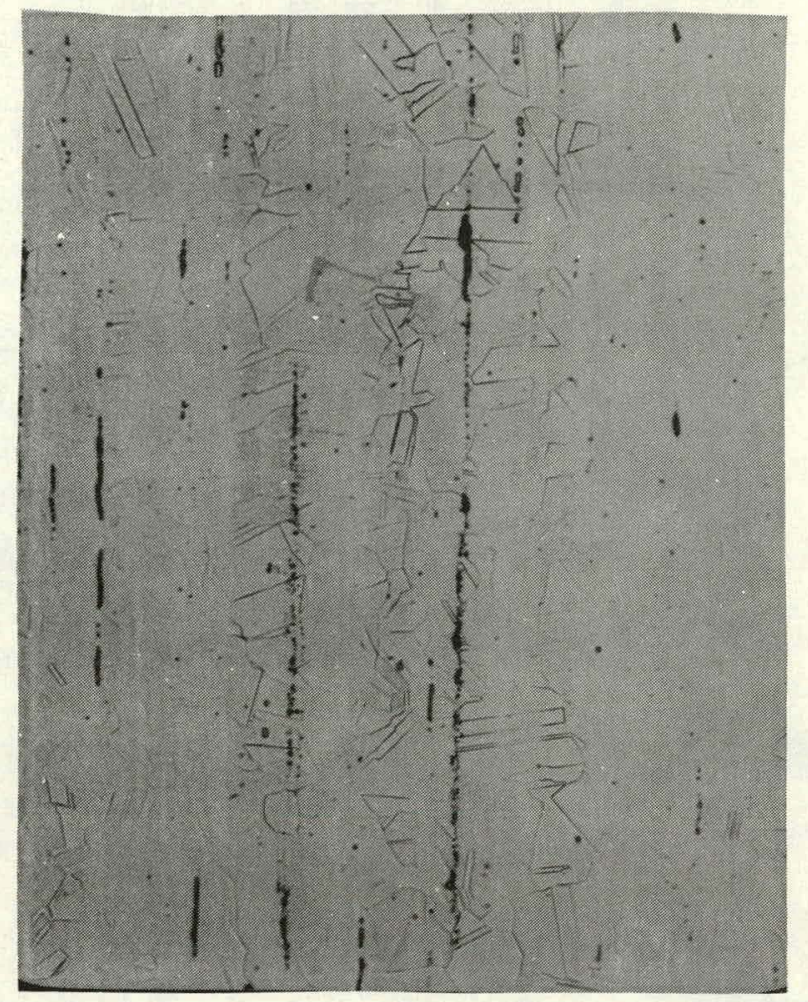

(4a)

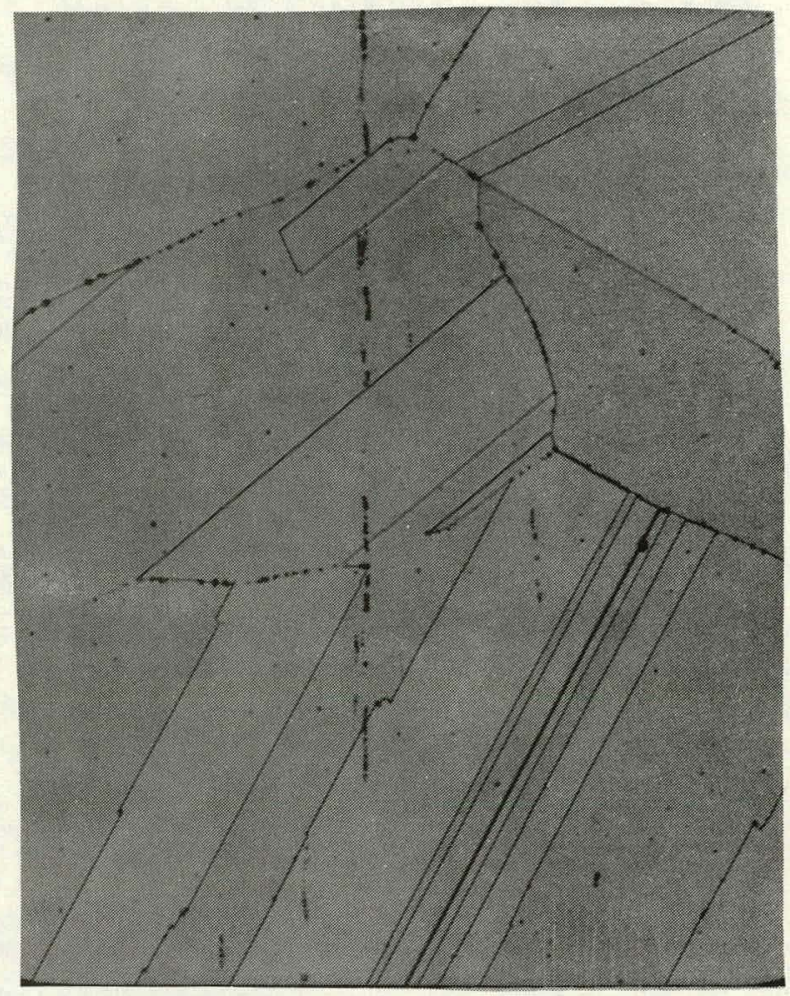

(4b)

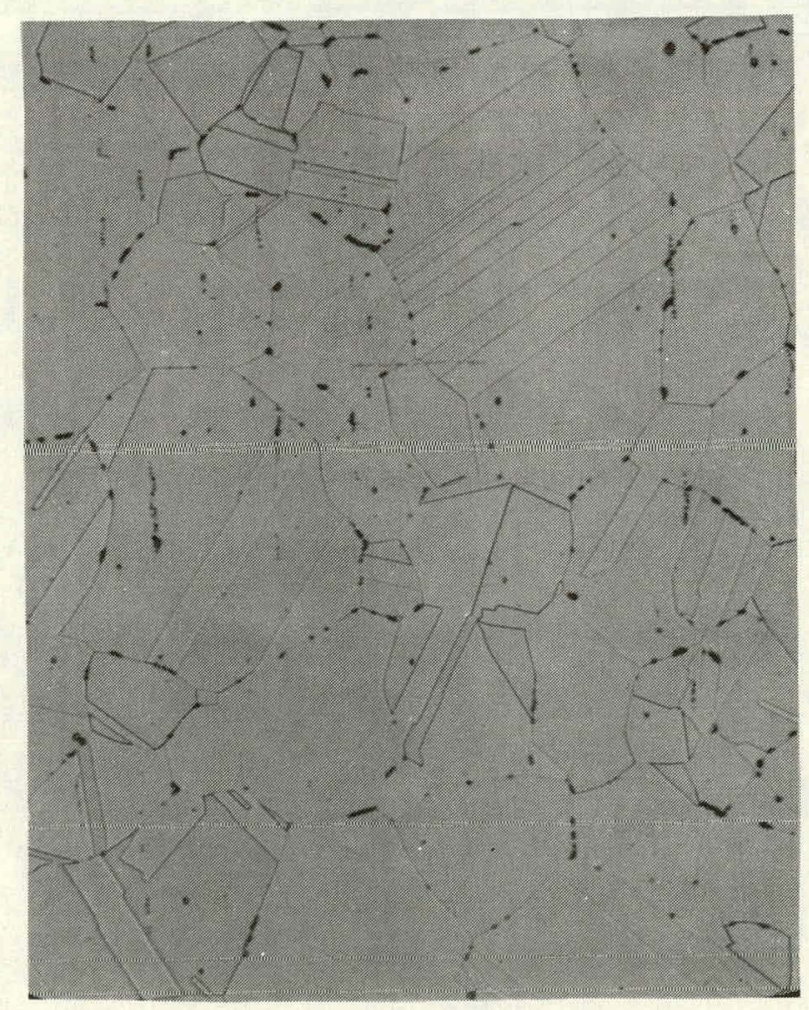

$(4 \mathrm{c})$

Figure 4. Micrographs of 21-6-9 Microstructures (250X) 


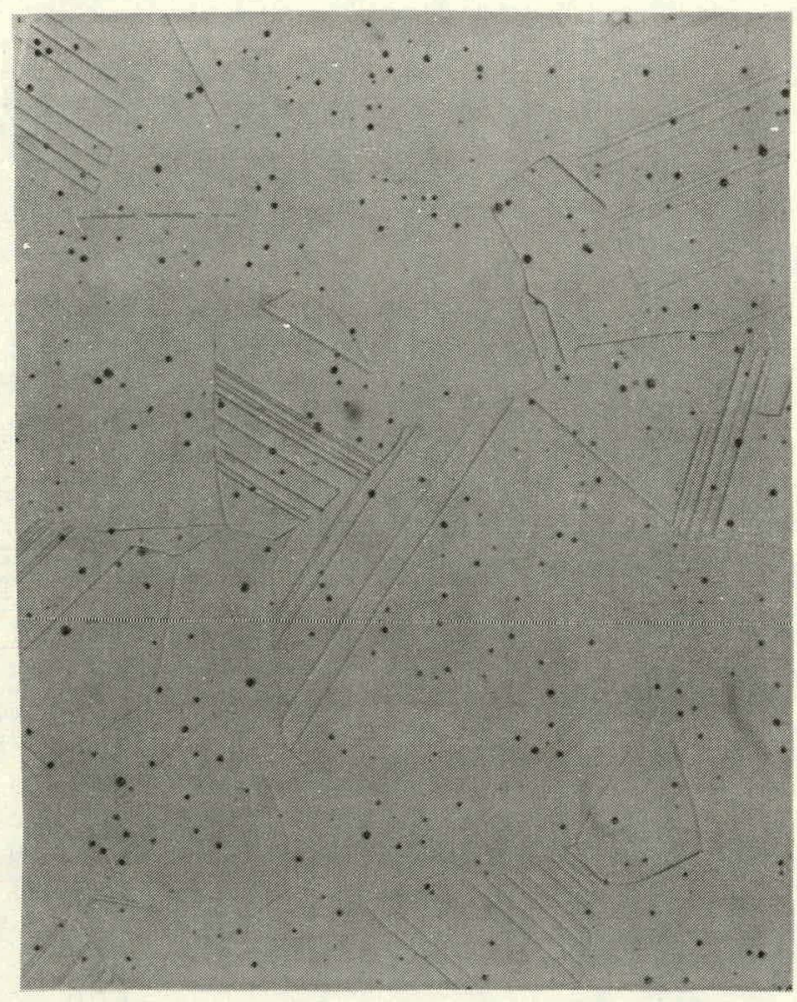

(a)

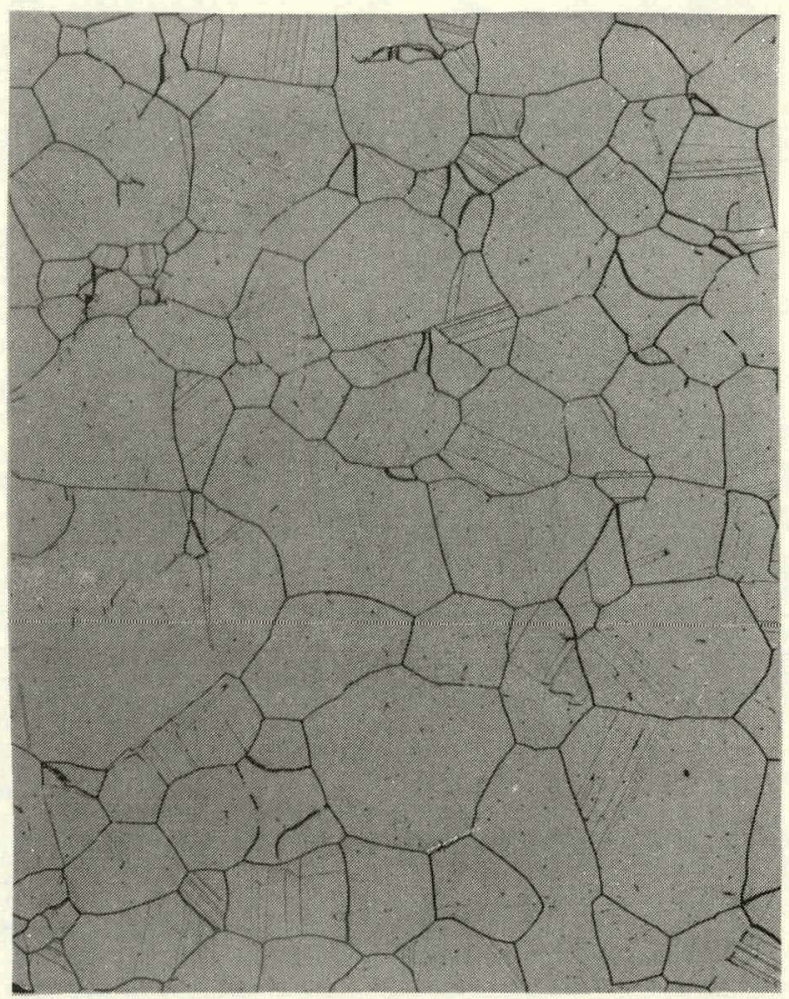

(b)

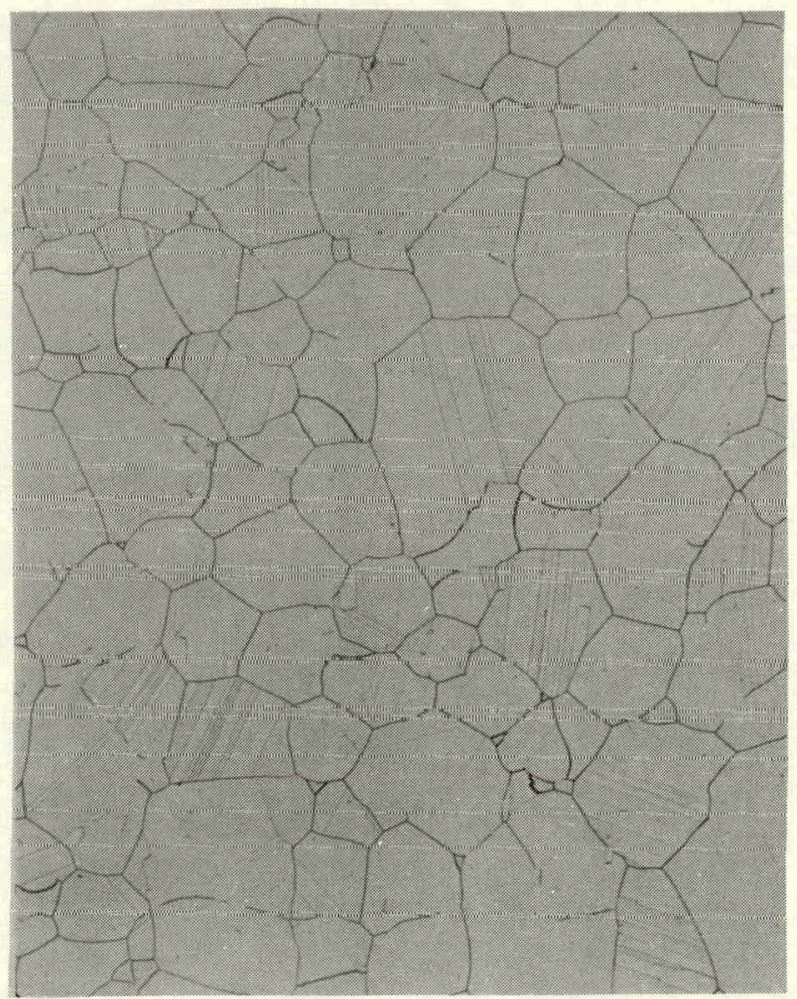

(c)

Figure 5. Micrographs of Hastelloy C-276 Microstructures. 


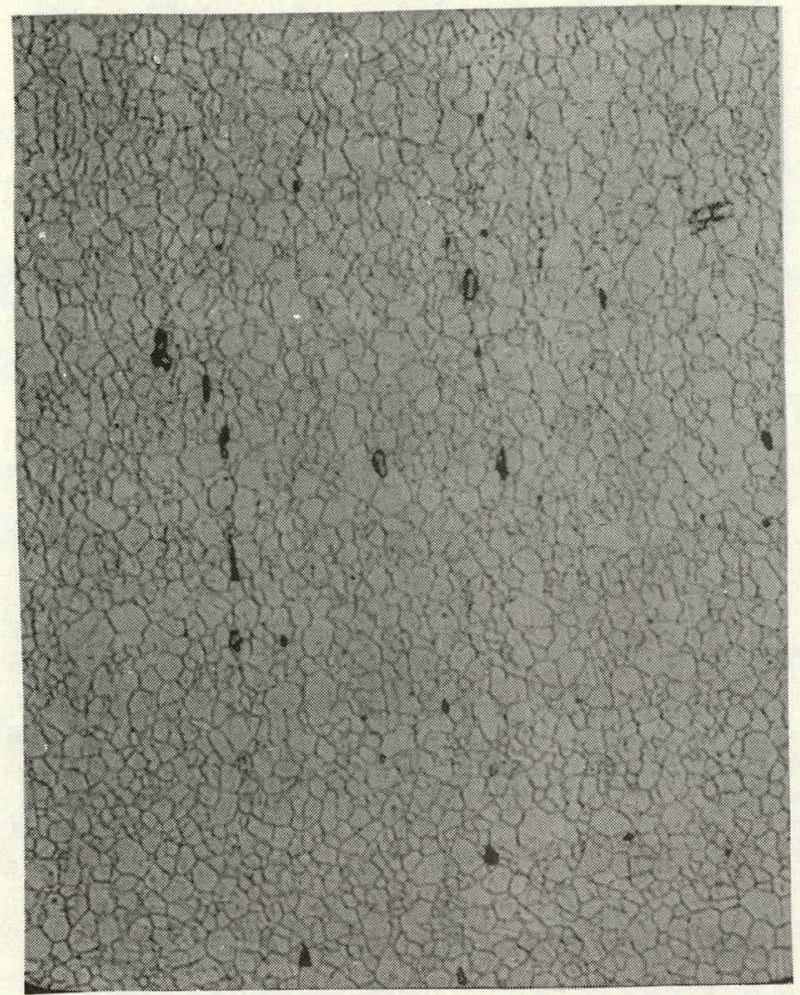

(a)

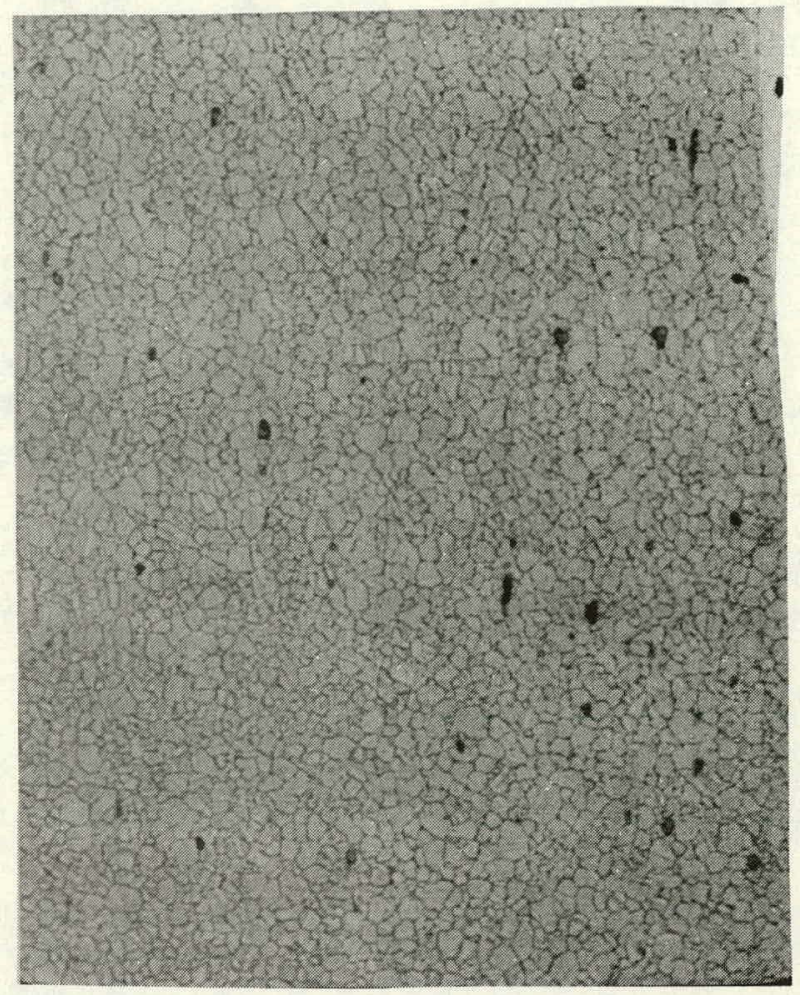

(b)

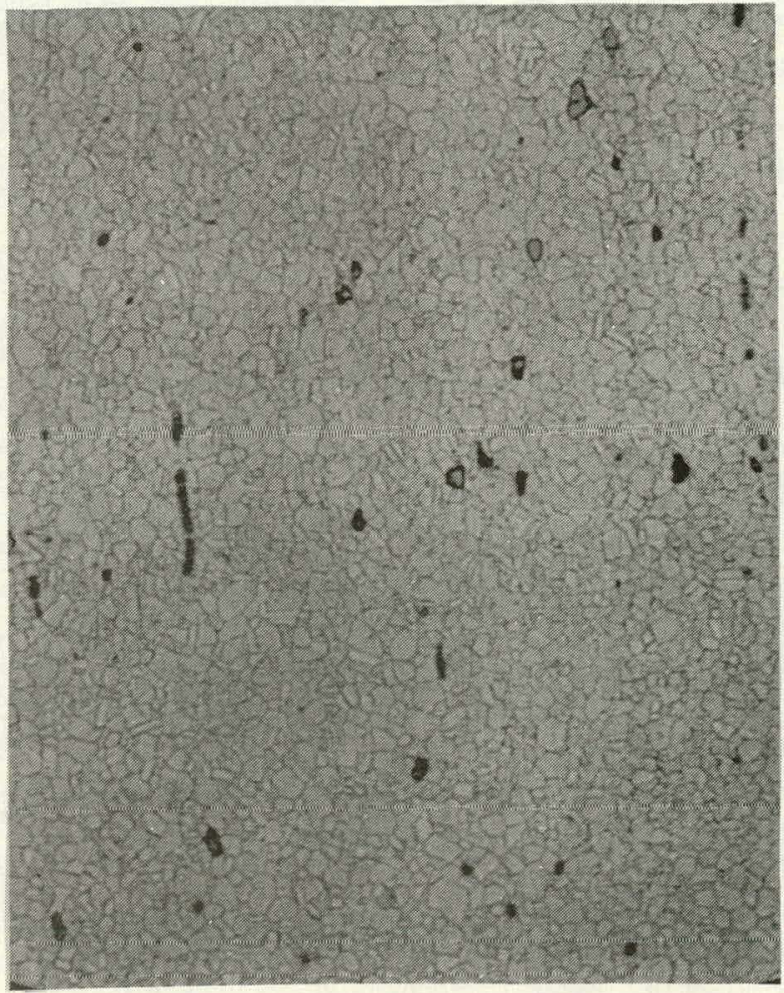

(c)

Figure 6. Micrographs of Inconel 625 Microstructures (250X) 


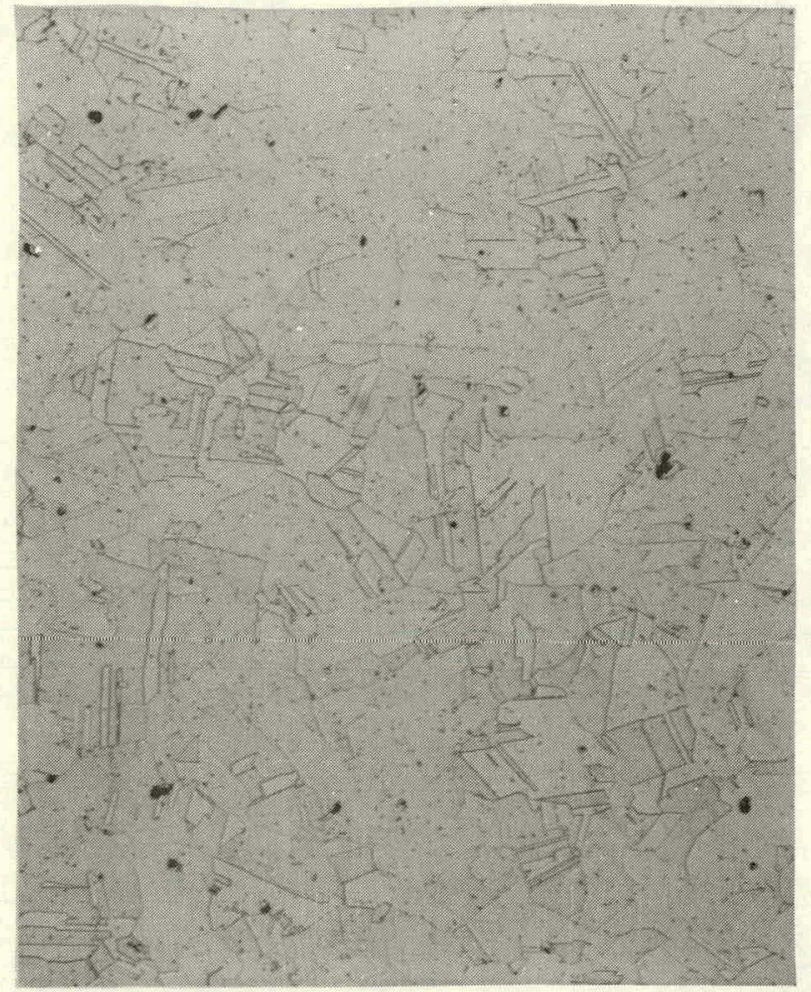

(a)

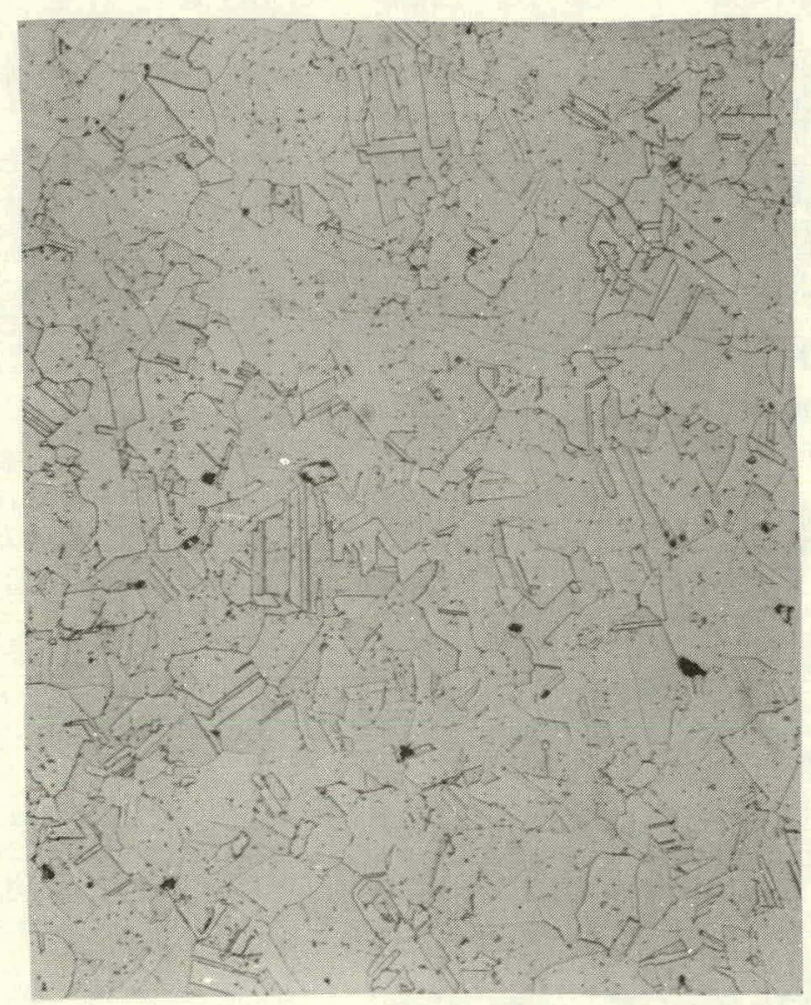

(c)

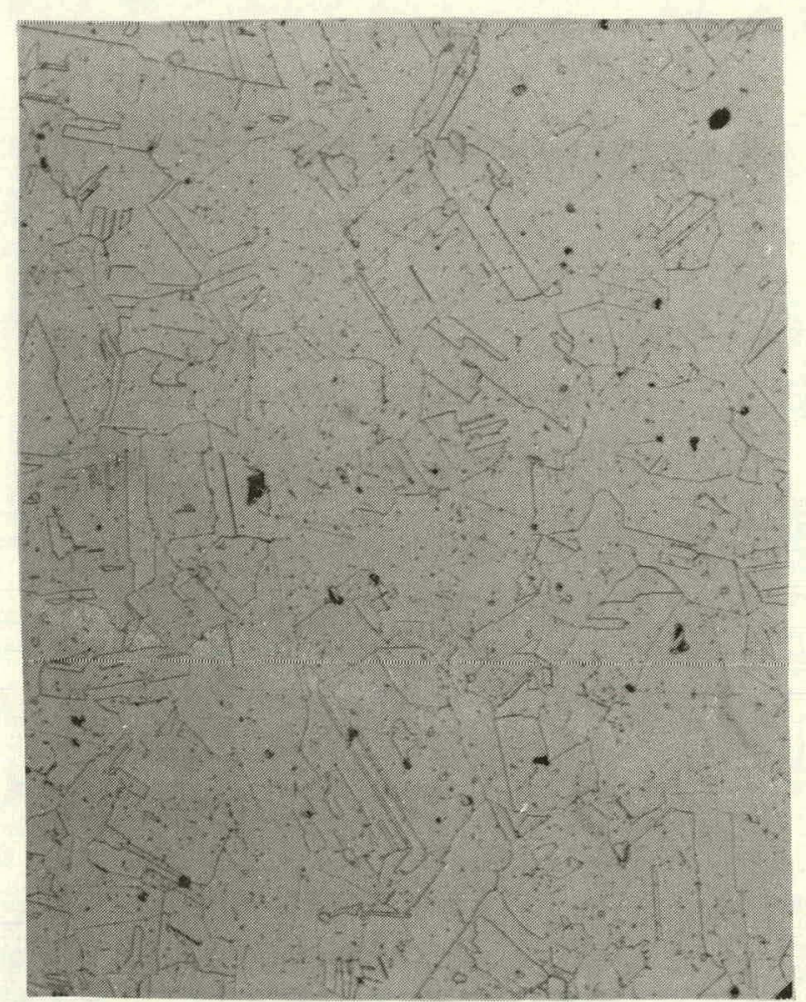

(b)

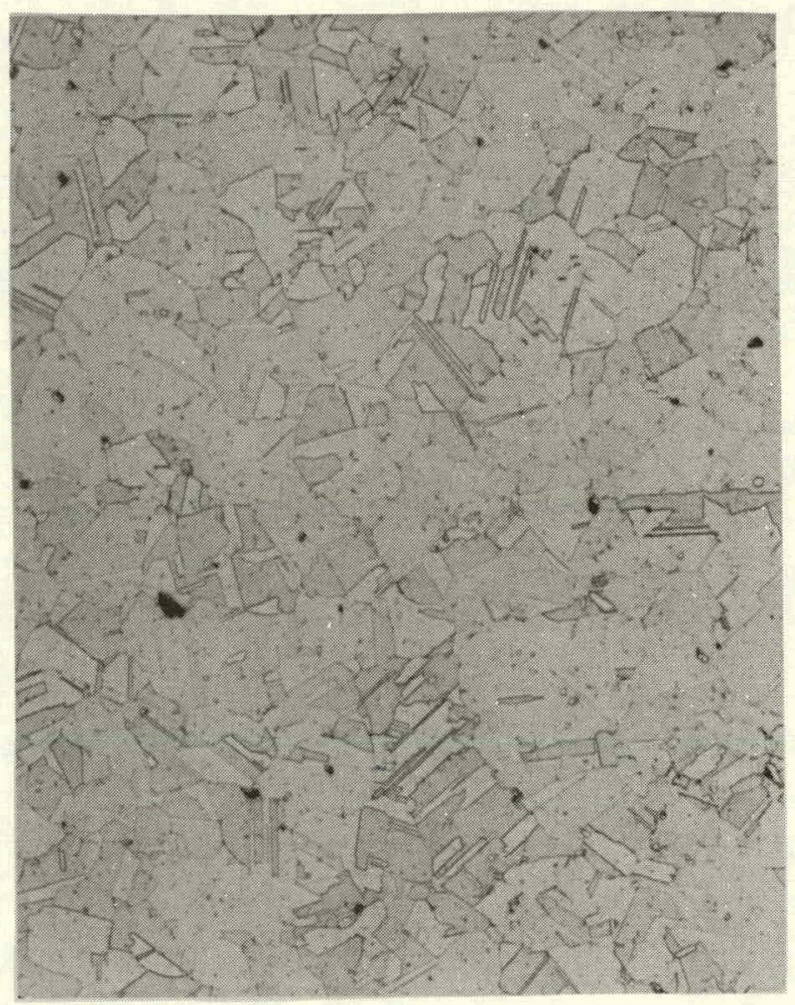

(d)

Figure 7. Micrographs of Inconel 718 Microstructures (250X) 


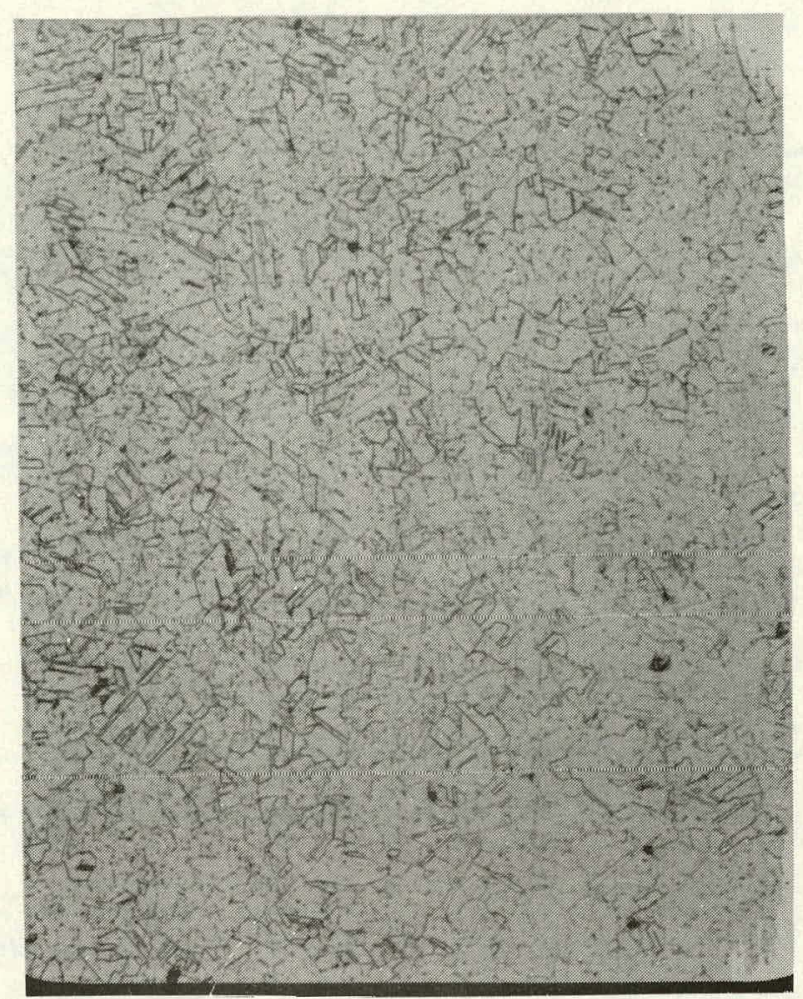

(e)

Figure 7. (Cont.) 


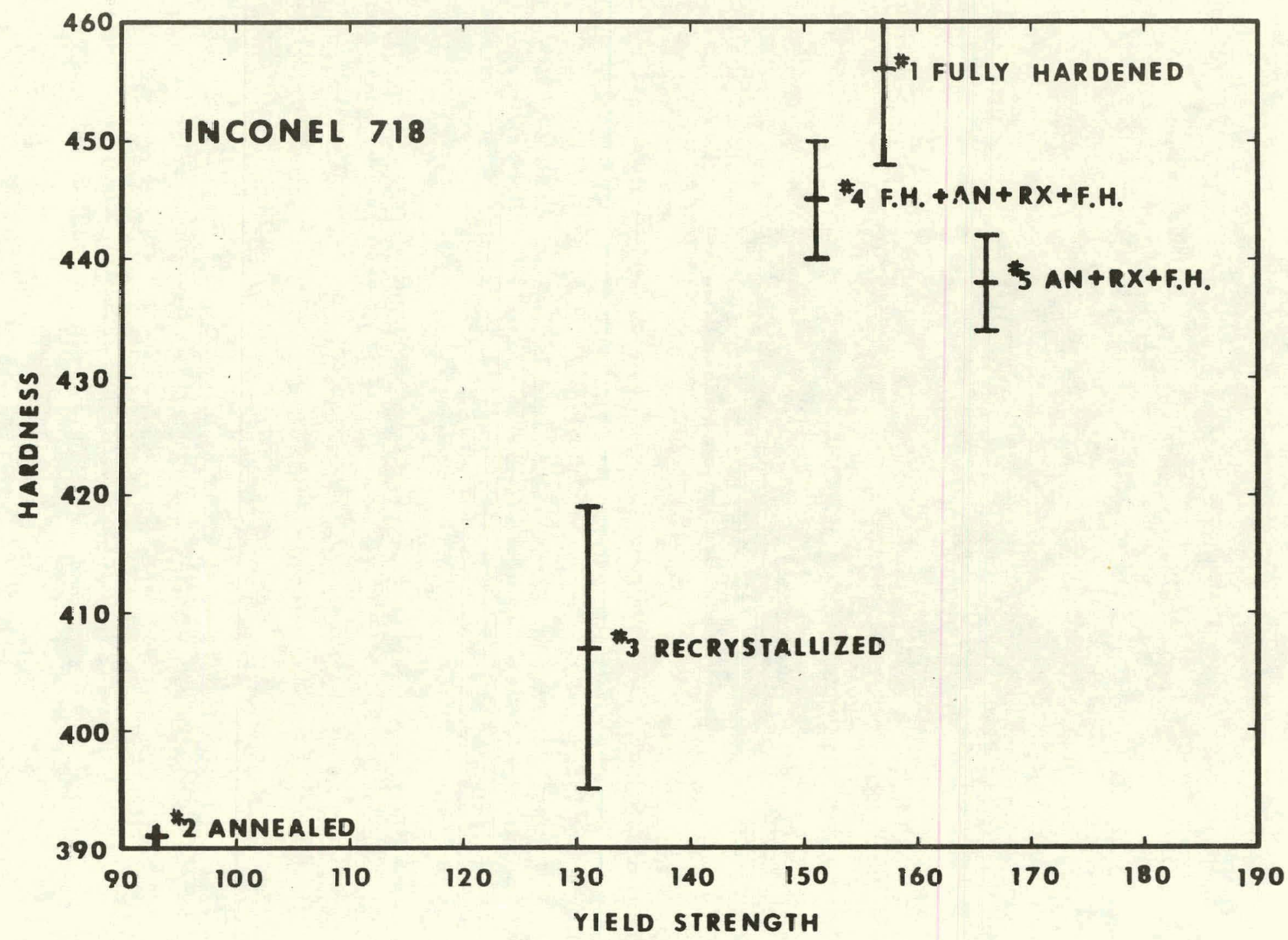

Figure 8. Eardness vs. Yield Strength for Inconel 718 Specimens. 


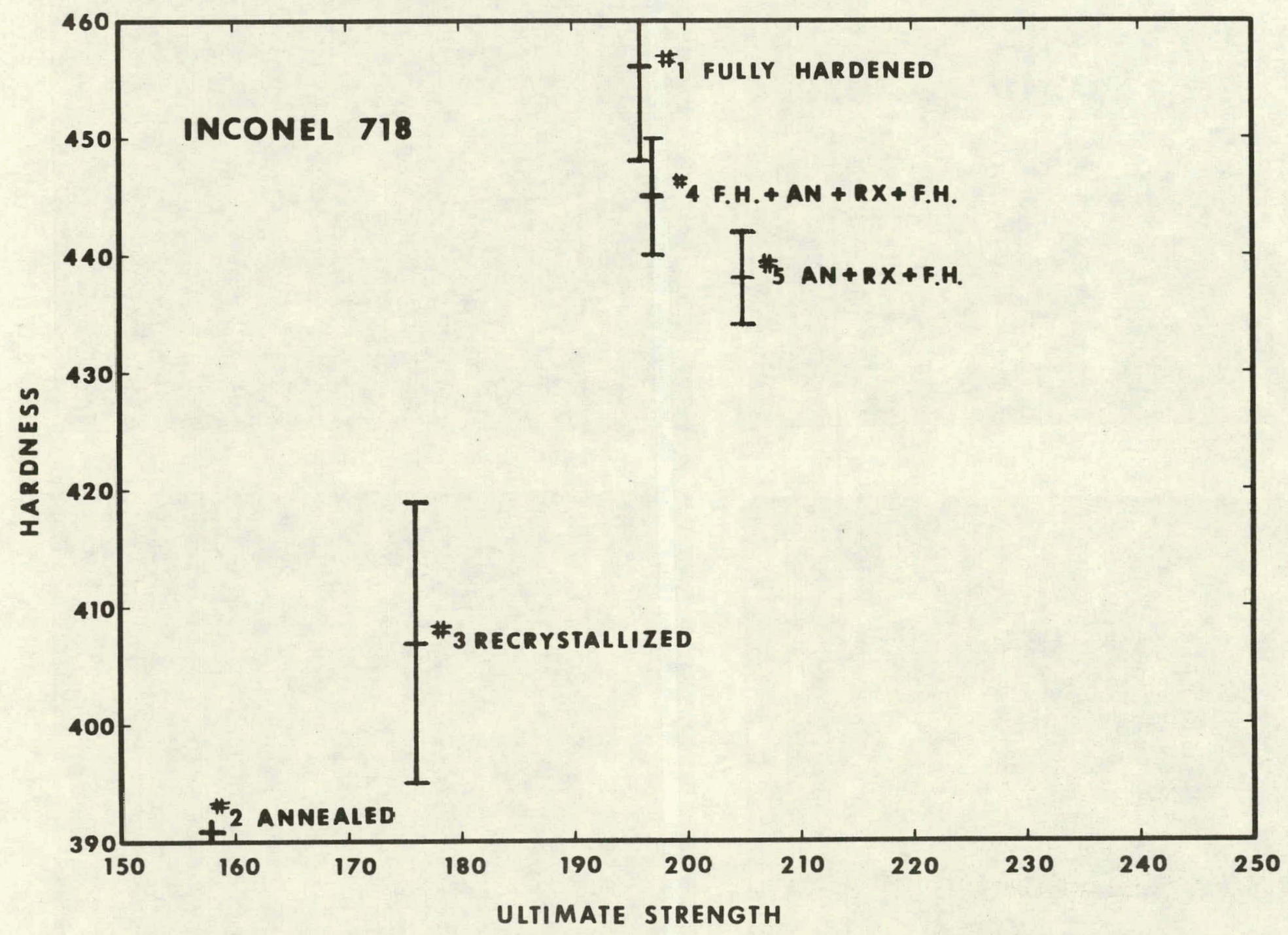

Figure 9. Hardness vs. Ultimate Tensile Strength for Inconel 718 Specimens. 


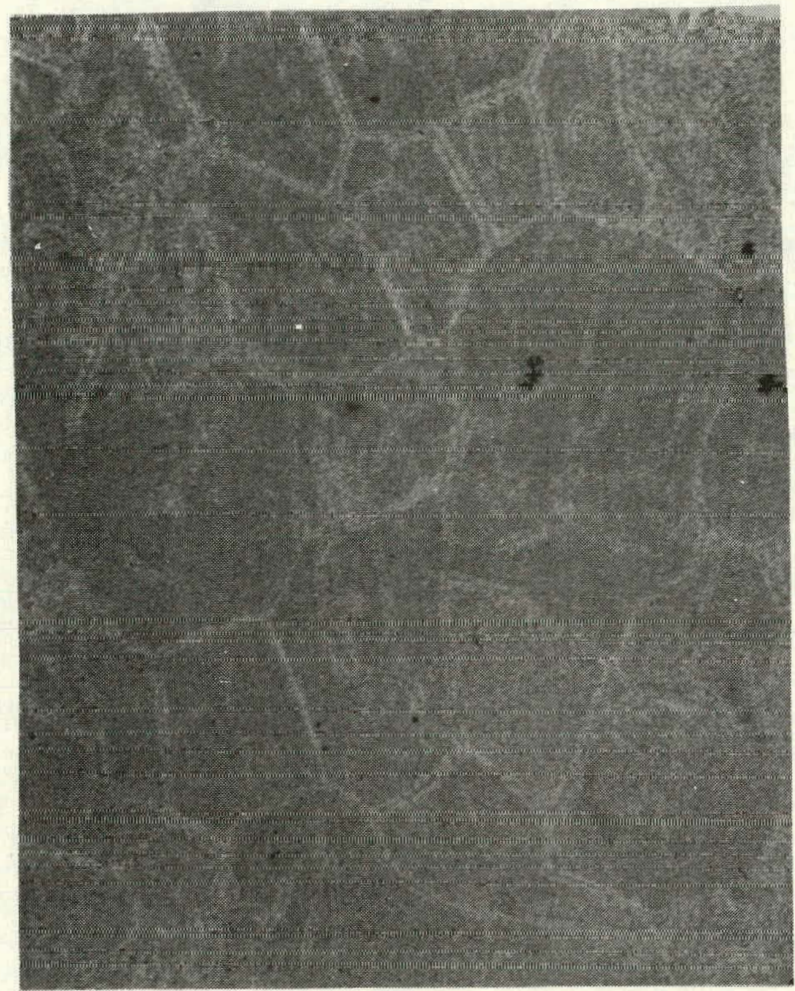

(a)

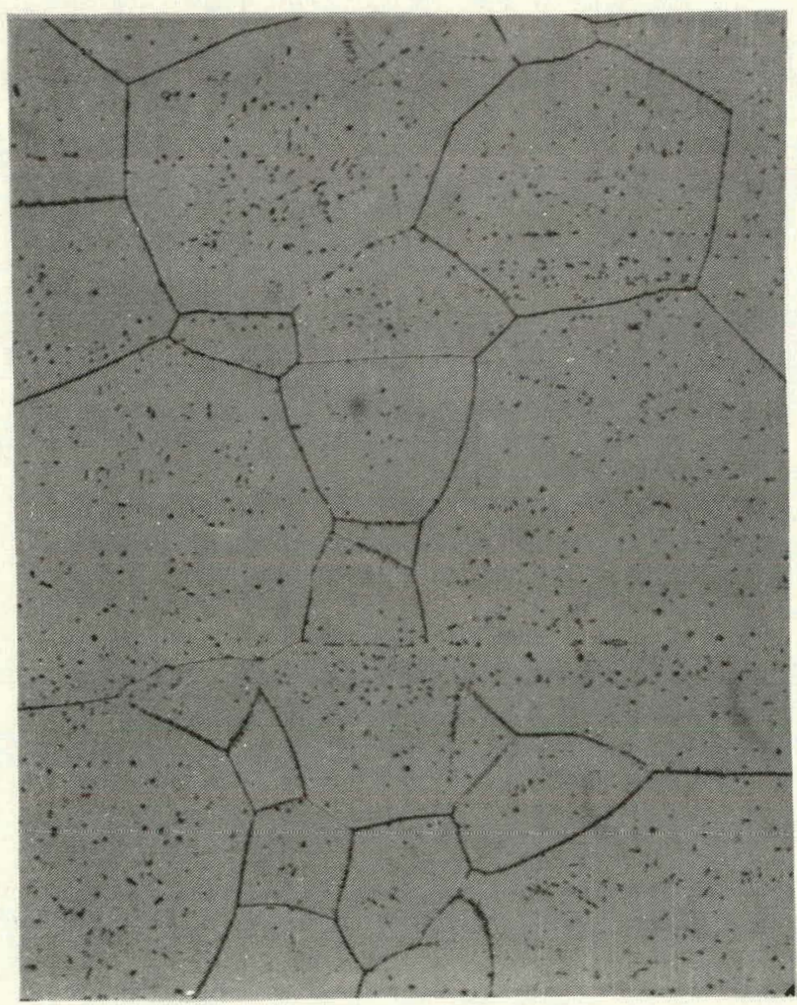

(c)

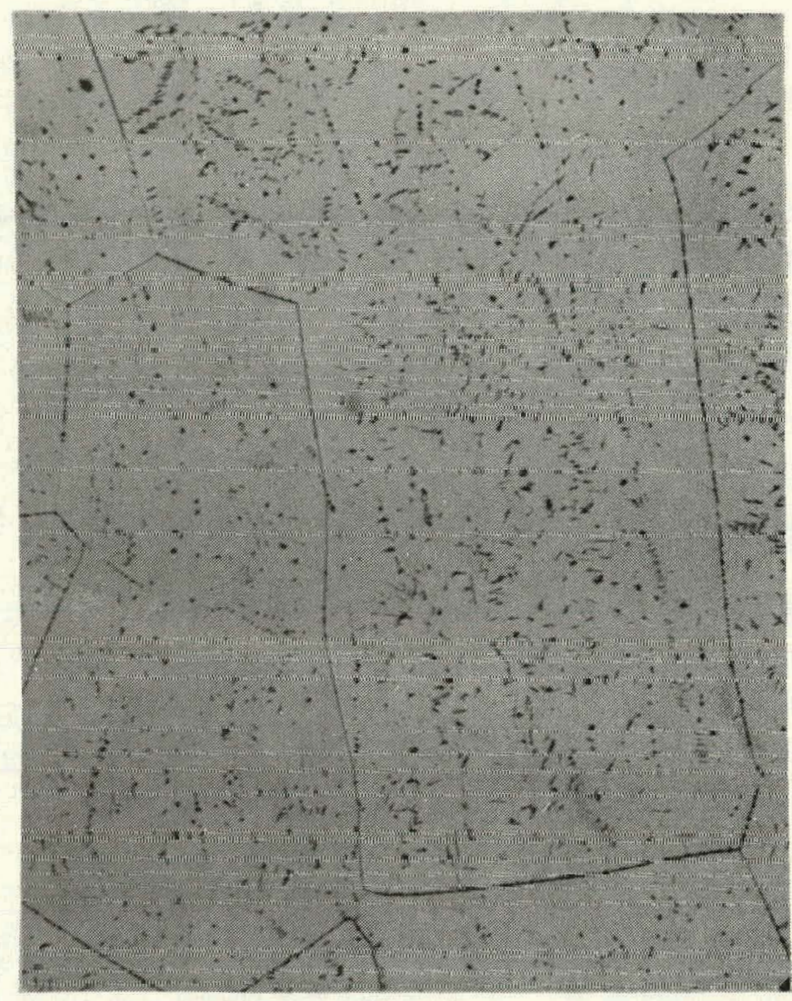

(b)

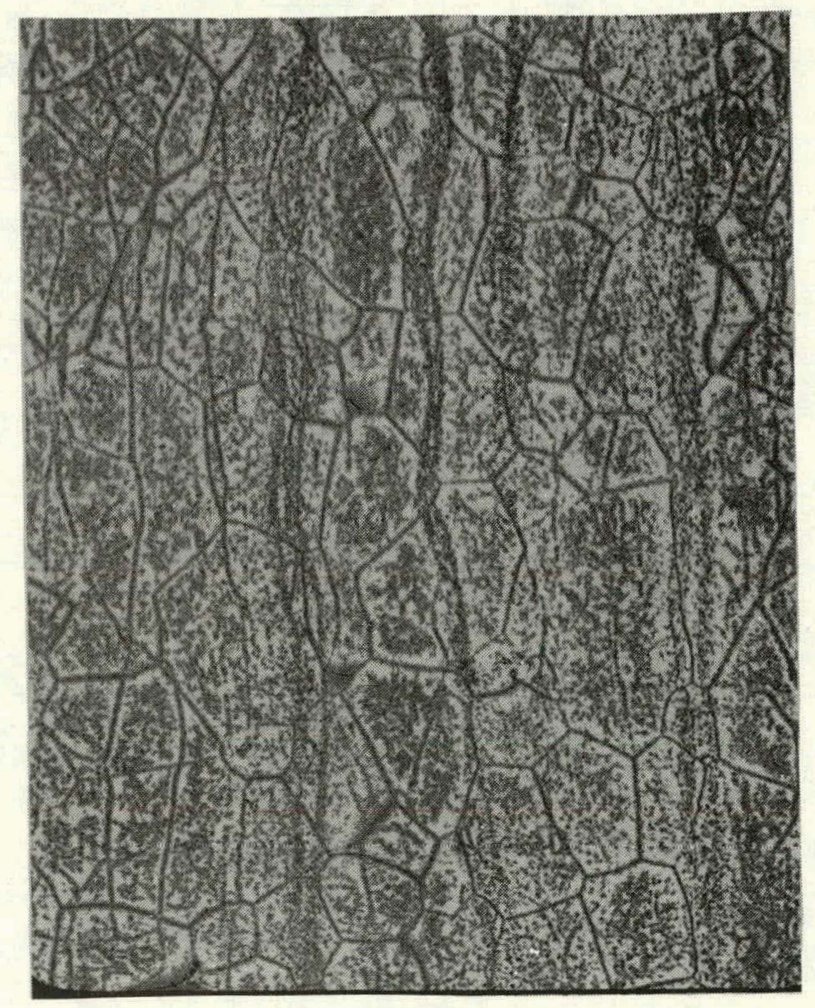

(d)

Figure 10. Micrographs of Titanium B-C Microstructures. 


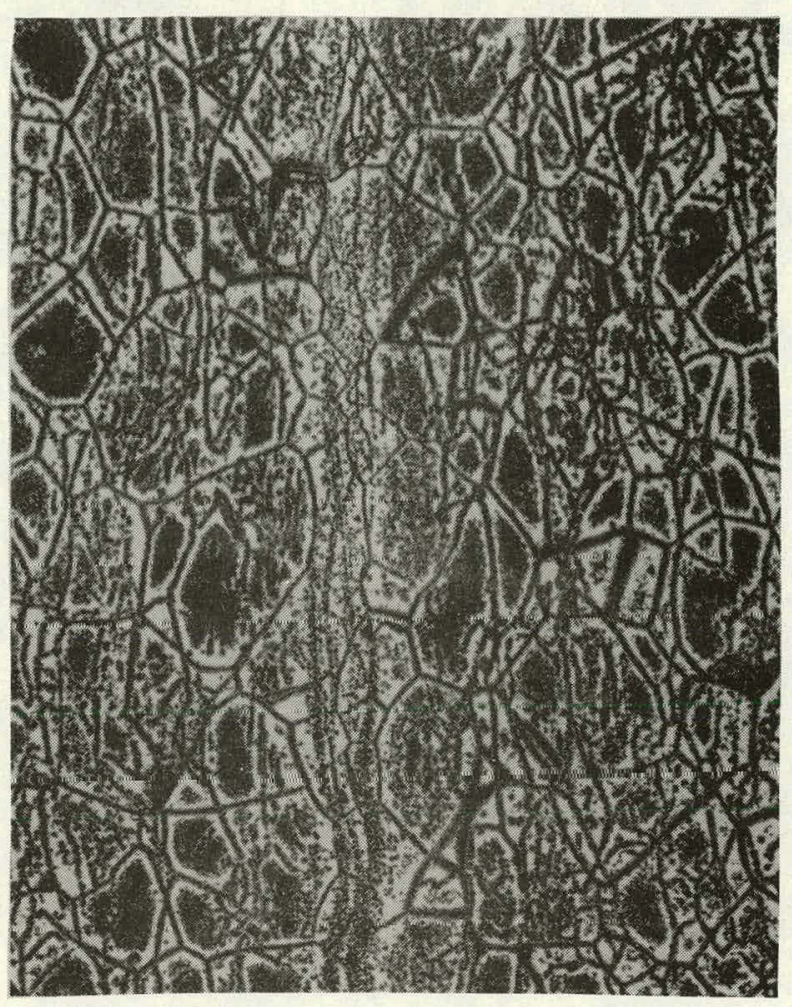

(e)

Figure 10. (Cont.) 


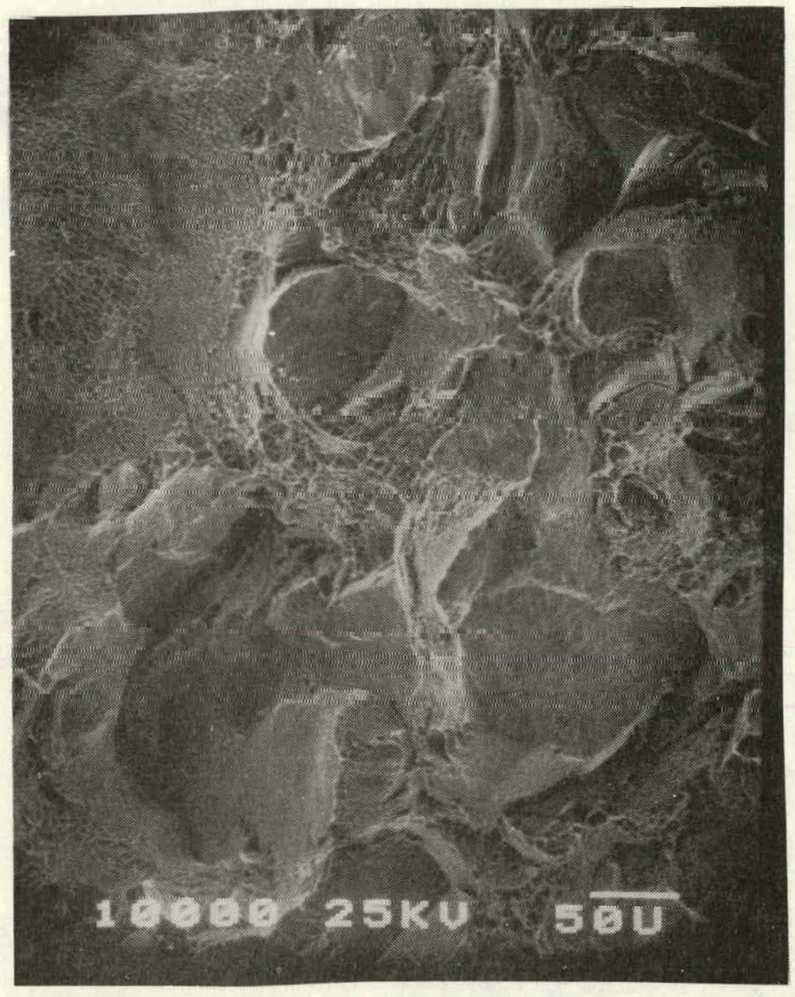

(a)

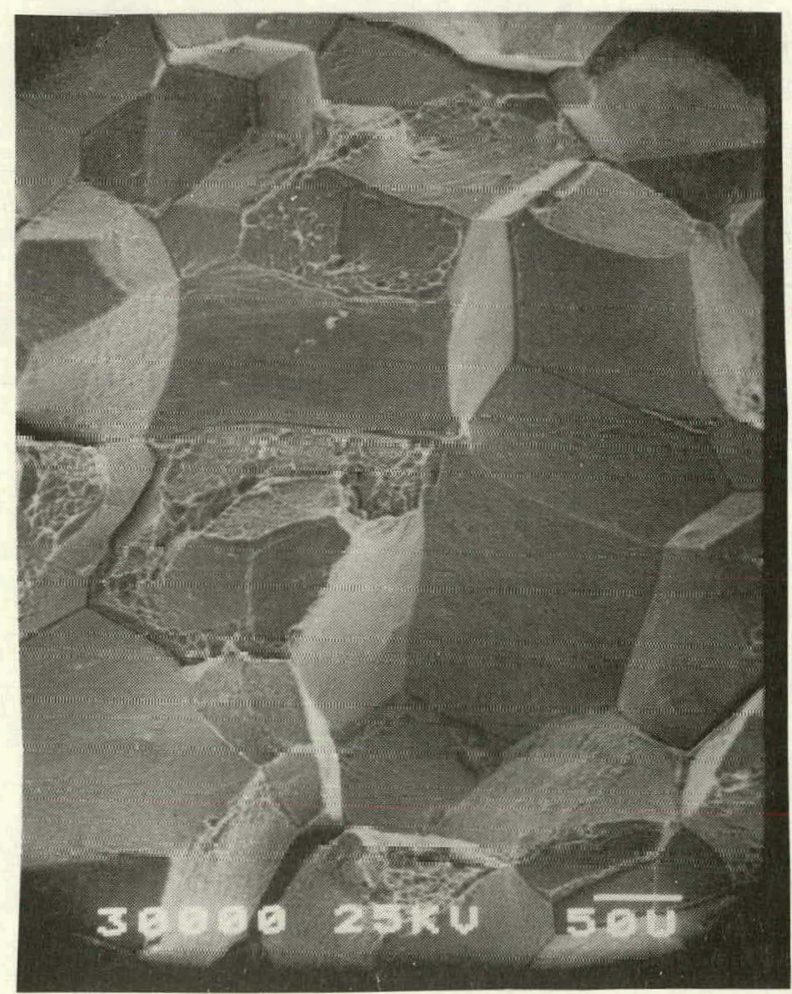

(c)

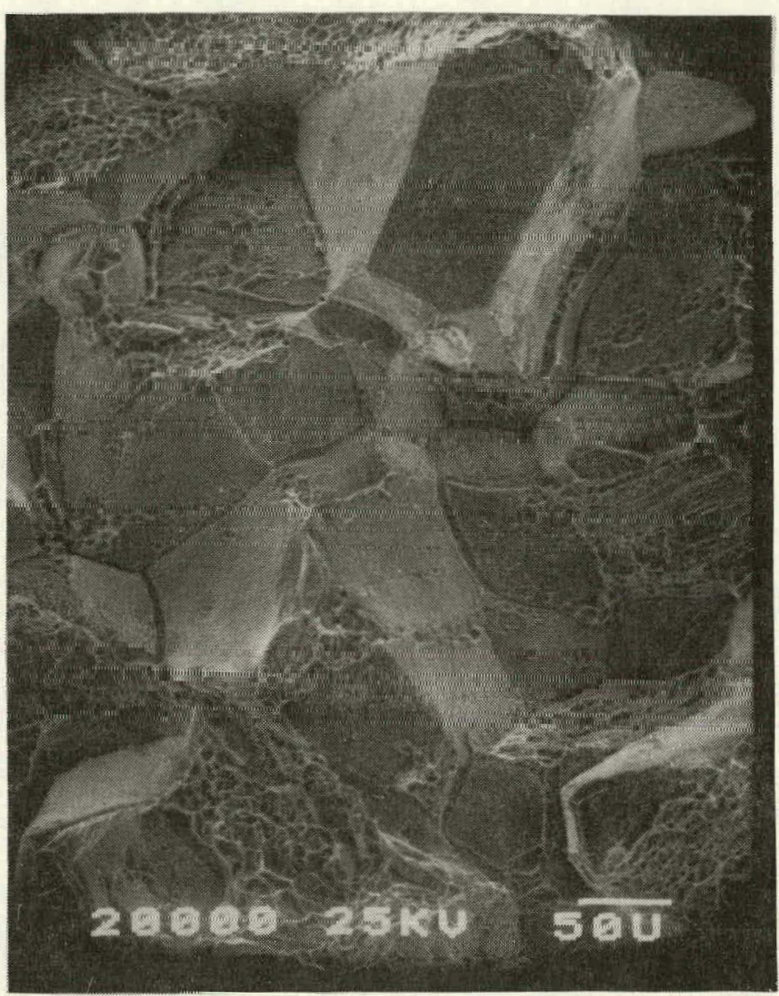

(b)

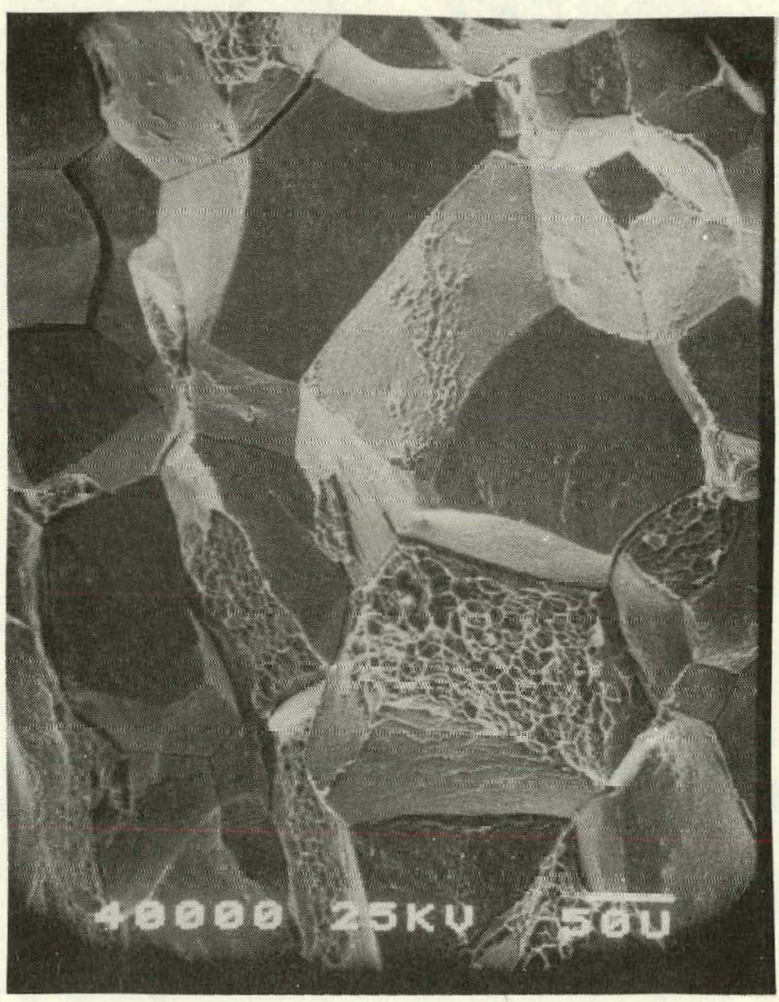

(d)

Figure 12. Structure Within Titanium B-C Fracture Surfaces at High Temperatures 


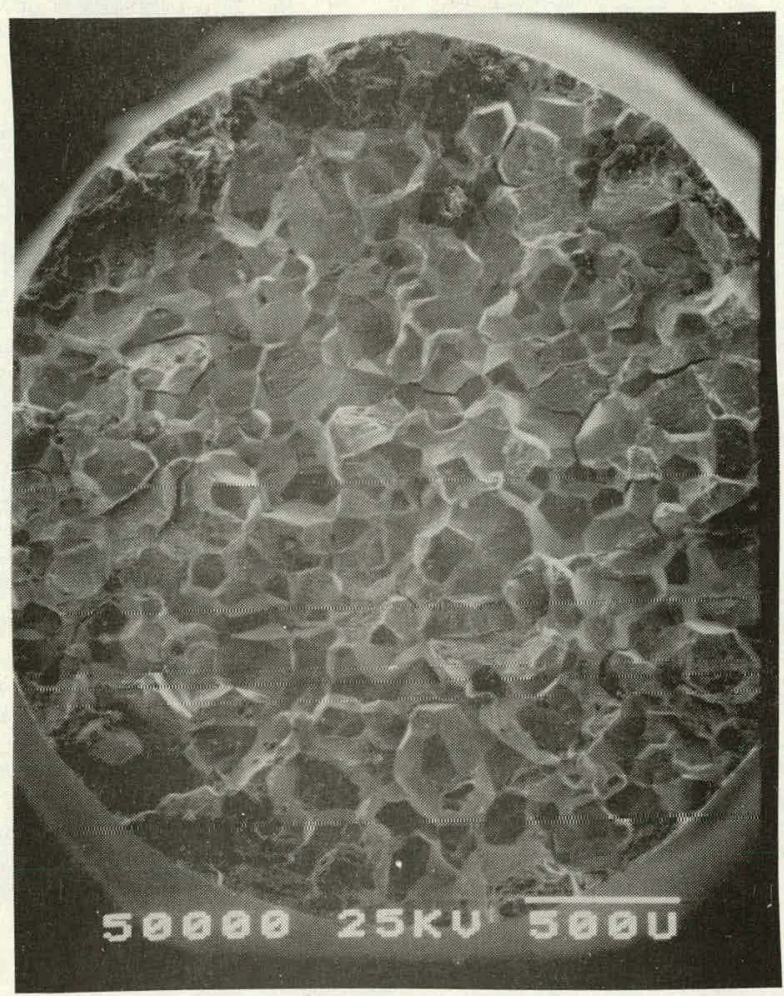

(e)

Figure 11 (Cont.) 


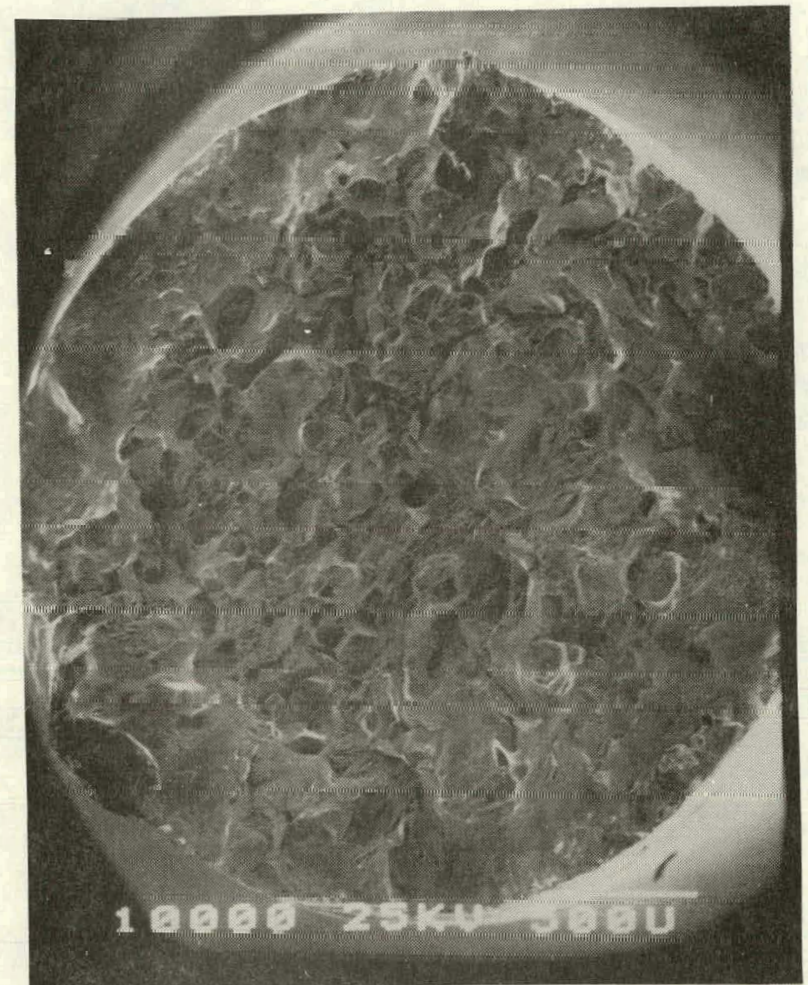

(a)

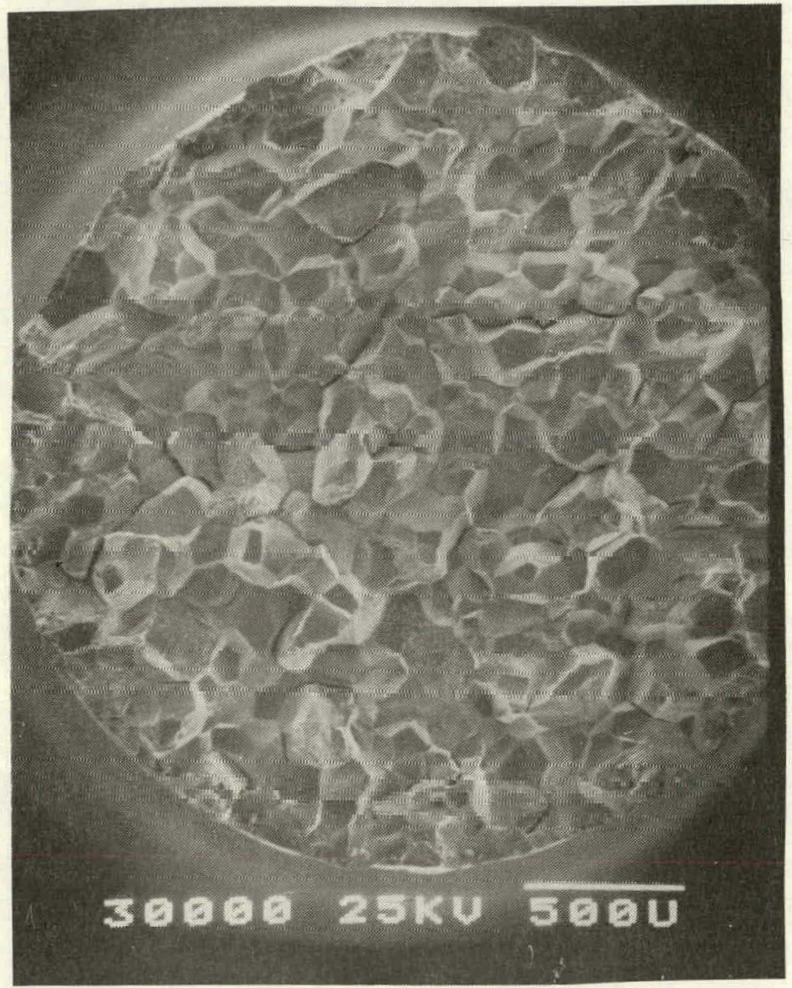

(c)

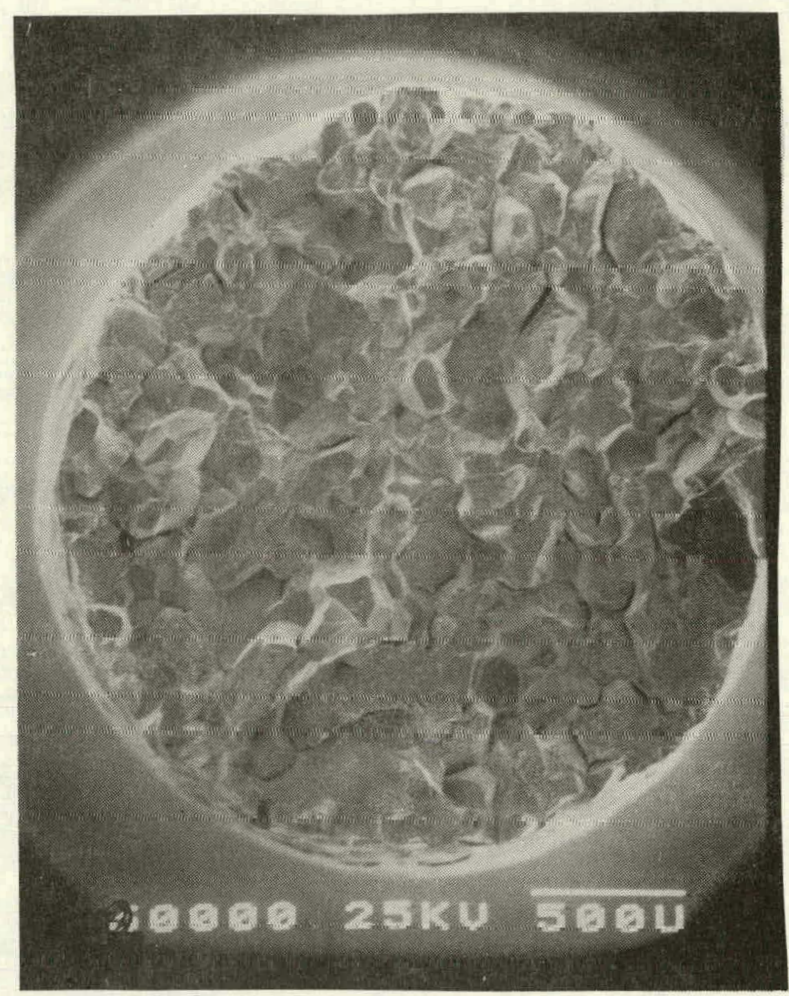

(b)

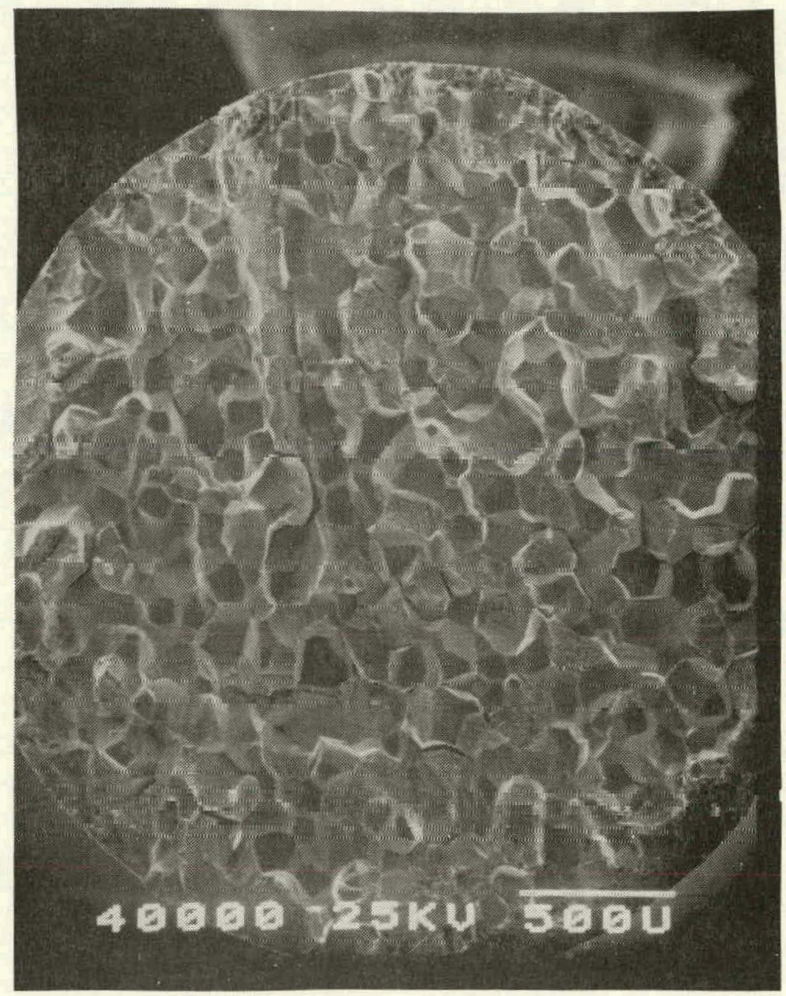

(d)

Figure 11. Fractographs of Titanium B-C Fracture Surfaces. 


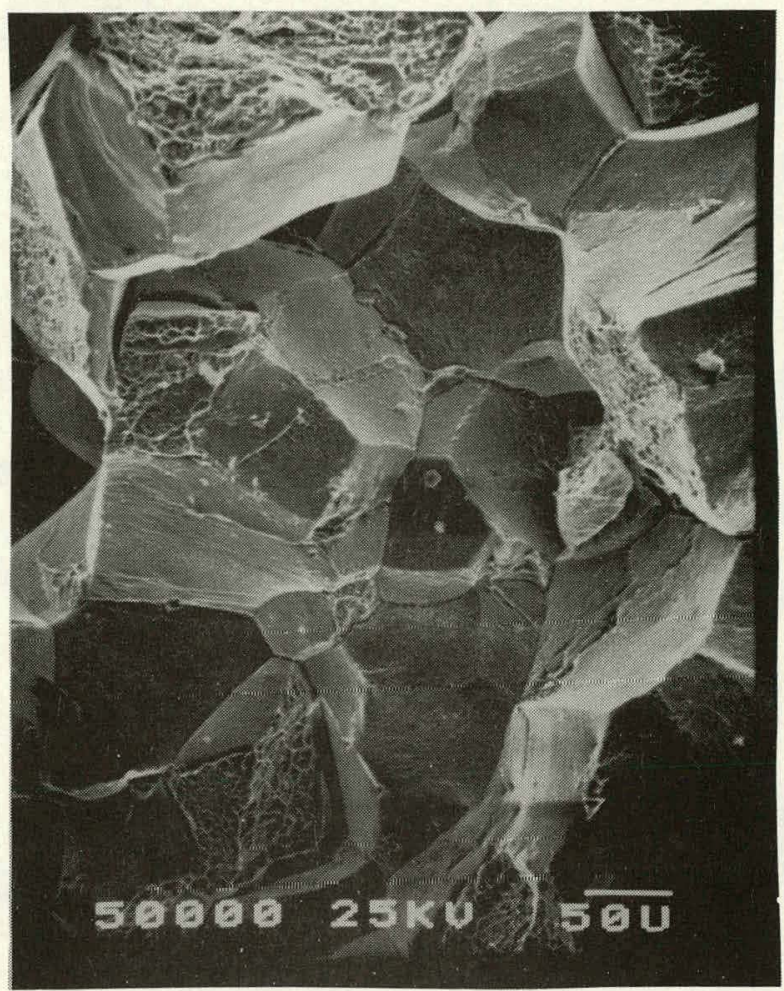

(e)

Figure 12 (Cont.) 
Distribution:

$\begin{array}{ll}1471 & \text { H. L. McCollister } \\ 1471-4 & \text { R. D. Snidow } \\ 2513 & \text { J. E. Kennedy } \\ 2513 & \text { A. K. Jacobson } \\ 2515 & \text { P. D. Wilcox } \\ 2515 & \text { L. C. Allen } \\ 2515 & \text { O. I. Burchett } \\ 2516 & \text { W. G. Perkins } \\ 2516 & \text { T. M. Massis } \\ 5840 & \text { N. J. Maynani } \\ 5841 & \text { R. B. Diegle } \\ 5841 & \text { L. J. Welrick (10) } \\ 5845 & \text { R. J. Eagan } \\ 5846 & \text { E. K. Beauchamp } \\ 3141 & \text { L. J. Erickson } \\ 3151 & \text { W. L. Garner (3) } \\ 3154-3 & \text { C. Dalin } \\ & \text { For DOE/TIC }\end{array}$




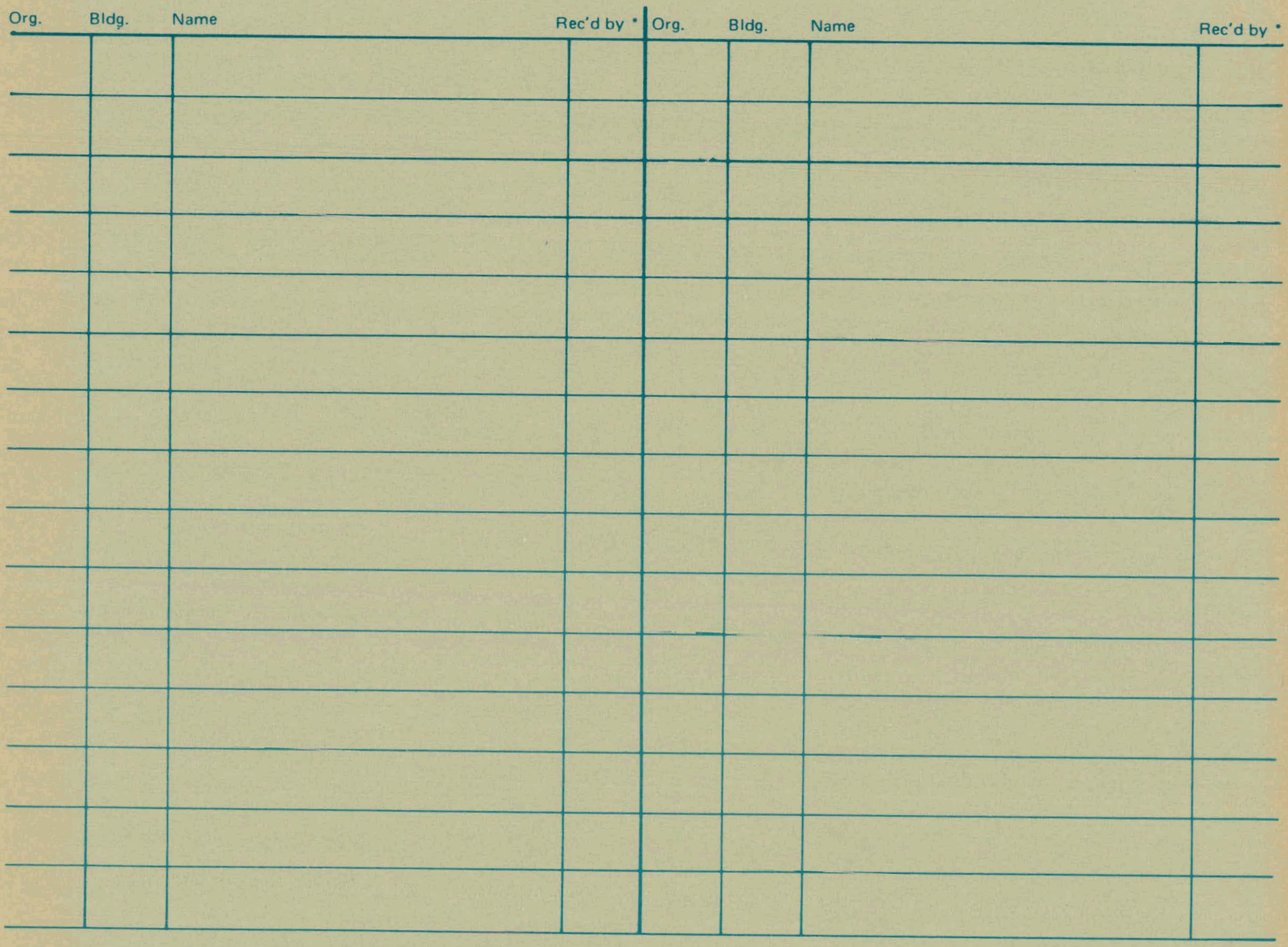

